University of Louisville

ThinkIR: The University of Louisville's Institutional Repository

Electronic Theses and Dissertations

1935

\title{
An activity program in an elementary school.
}

Bessie Terrell Meyer 1890-1988

University of Louisville

Follow this and additional works at: https://ir.library.louisville.edu/etd

Part of the Educational Methods Commons

\section{Recommended Citation}

Meyer, Bessie Terrell 1890-1988, "An activity program in an elementary school." (1935). Electronic Theses and Dissertations. Paper 1830.

https://doi.org/10.18297/etd/1830

This Master's Thesis is brought to you for free and open access by ThinkIR: The University of Louisville's Institutional Repository. It has been accepted for inclusion in Electronic Theses and Dissertations by an authorized administrator of ThinkIR: The University of Louisville's Institutional Repository. This title appears here courtesy of the author, who has retained all other copyrights. For more information, please contact thinkir@louisville.edu. 


\title{
UNIVERSITY OF LOUISVILLE
}

\section{AN ACTIVITY PROGRAM IN AN ELEMENTARY SCHOOL}

\author{
A Dissertation \\ Submitted to the Faculty \\ of the Graduate School of the University of Louisville \\ In Partial Fulfiliment of the \\ Requirements for the Degree \\ of Master of Arts
}

Department of Education

By

Bessie Terrell Meyer -

Year

1935 
TABLE OF CONTENTS

Page

Introduction and Purpose..................... I

I. Historical Sketch of the Activity Movement....... 4

II. Philosophical, Psychological, Biological and

Scientific Aspects of the Activity Movement..... 19

III. Tracing an Activity Program in One Public School.. 33

IV. Criteria for Evaluating the Activity Movement.... 83

V. Evaluation of the School

in the Light of Acceptable Criteria.......... 89

VI. Pertinent Findings in Previous Investigations..... 99

VII. A Plan for the Future................... 130 Bibllography

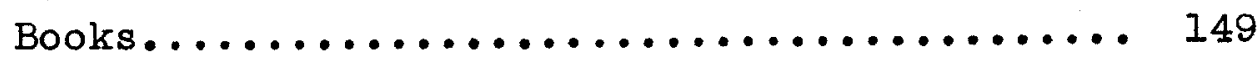

Periodicals...................... 153 
INTRODUCTION

THE PURPOSE 
The field of elementary education has felt peculiarly the invasion of the activity program into its ranks. Regardless of conviction or ultimete conclusion, it is a force to be reckoned with by all thinking educators. It is the purpose of this study to consider the problem, "How an Activity Program Can Enrich an Elementary School." By "activity" is meant purposeful experiencing in life-like situations. An activity program is the provision for such experiences as are rich in the possibilities for growth, that necessitate the use of related fields of knowledge, that develop the ability to work and play in a group and that result in a better soclal adjustment than would be possible in an old-type school.

It must be pointed out that the problem under discussion will necessarily be a modified type of activity program. From the standpoint of personal conviction, the writer is definitely committed to the philosophy of the new education. However, as a part of a large pubIic school system, certain administrative conformity is necessary. This conformity in no way hampers creative thinking, and the attempt will be made to show what contribution may be made by progressive teaching in a public school. 
It is the plan to trace the progress of activity developments in the Nicholas Finzer School for the past twelve jears. An informal analysis will be made of exlsting conditions with a pointing out of weaknesses and whatever there has been of success. An effort will be made to show the evolution of content and methods. Causal factors, influencing the teachers' thinking, will be discussed and deductions drawn.

Criteria for evaluating the activity program in the Nicholas Finzer School will be set up and an attempt made to measure the school by the se standards.

A report of investigations in the field will be given. Since this problem is concerned with the activity program in a public school, studies bearing upon this phase of the movement will be given primary emphasis. However, a certain number of studies dealing with quantitative analysis and scientific appraisal of the newer practices in public schools will be included to point out more recent trends along the line of measurement in progressive education.

It must be emphasized, in this connection, that it is not the purpose of this study to make a quantitative analysis of the activity program in the Nicholas Finzer School. No effort shall be made to prove that results 
are superior to those which could be secured with another type of organization, nor shall any attempt be made to appraise scientifically, the outcomes achieved by this activity curriculum. This study is concerned only with a consideration of those experiences which provide for socialization, unfication and integration. The historical background of the activity movement, both in Europe and in America will be presented, with a pointing out of contributions made by earlier educators to present day thinking and practice.

Certain basic principles of the sciences of philosophy, psychology, biology and science will be discussed, with a pointing out of their bearing upon education. Finaliy, a program for the future in the Nicholas Finzer School will be laid out. This will embody suggestions for the improvement of the physical plant as well as a summary of curricular plans and procedures. 
CHAPTER I

HISTORICAL SKETCH OF THE ACTIVITY MOVEMENT 
HISTORICAL SKETCH OF THE ACTIVITY MOVEMENT

The theory of activity in education is not new. It is the purpose of this chapter to point out evidences of the beginnings of the activity movement in the philosophies and procedures of the educators of an earlier day. In using the term "activity movement", its present day conception is considered. While many statements have been made in definition of its meaning, Adams gives a clear and comprehensive explanation: "An activity has been defined as a learning situation which meets the interests and felt needs of children and leads to better adjustments than in the traditional school organization. It stresses the fine art of successful living together through which there is an acquisition of knowledge. Yet acquaintance with our racial culture and our social heritage is given no subordinate place, for an activity involves many kinds of experiences and draws upon many fields of knowledge."I

1. Adams, Fay. The Initiation of an Activity Program into a Public School. Bureau of Publications, Teachers College, Columbia University, New York, 1934. p. 70 . 


\section{European Implications}

It is interesting to note that the roots of the present activity movement in America may be traced to the Renalssance period. ${ }^{1}$ The humanistic schools of the fourteenth and fifteenth centuries emphasized a close connection between education and life. The development of the body through active participation in sports, the importance of independent judgment rather than an accumulation of facts, and the soclal utility of education were stressed by the humanistic and social realists. Vittorino de Feltre (1378-1446), head of the most noted of the humanistic schools. La Casa Giocosa, at Mantua, held strongly to the belief of following "nature's lead".

Even more critical of the current school procedures of the day were the social realists such as Rabelais, Montalgne, Mulcaster, Milton and Locke.

The humanistic schools, through their leaders, anticipated by five or six centuries the creed of the present day activity school. As has been pointed out, their emphasis upon judgment, initiative, and experiencing rather than upon subject matter to be learned, is identical with

1. Woody, Thomas. "Historical Sketch of Activism", Thirty-third Yearbook of the National Soclety for the Study of Education. Bloomington Public School Publishing Company, 1934. Part II, p. II. 
present day belief. They realized that education is social and that there is constant growth through experiencing in a social situation. It would seem that in this particular phase, the humenistic school made its greatest contribution to modern activity schools.

Comenius held similar ldeas upon nature as it affected man and his education. He pointed out that man is gifted with senses, and "there is nothing whatever that can escape their notice.........there is nothing in the universe which cannot be compassed by a man endowed with sense and reason." Also that "man is imbued not merely with a tolerance of but with an actual appetite for toil. This is evident in childhood and accompanies us through life. For who is there that does not always desire to see, hear, or handle something new?......... In a word, the eyes, the ears, the sense of touch, the mind itself, are, in their search for food, ever carrled beyond themselves; for to an active nature nothing is so intolerable as ease and sloth." He held that man was to be educated "by being actually engaged in those things to which his nature Impelled him." 1

Comenius made a very definite contribution to the present new education when he stressed sense training and the ability to "engage in those things to which his nature impelled him."

1. Keatigne. Comenius, McGraw-Hill, 1931. pp. 27-28. 
In setting up criteria for judging units of work, present day educators Insist upon adequate opportunities for "sense experiences" and an active engaging in natural situations. In listing the qualities of a good teaching unit, Harap says, "It should include much pupil activity and involve a variety of direct sense experiences". I

Rousseau, following Comenius, stated his educational principles in E'mile. ${ }^{2}$ They embodied many of the problems which confront modern progressive educators today. In E'mile, he says, "Nature would have'children be children before being men"; "to live is the trade I wish to teach him"; "our instruction begins when we begin to live"; "the master should not give precepts, but should cause his pupil to find them"; "hygiene is the best part of medicine"; "make your pupil attentive to natural phenomena, and you will make him curious; but in order to nourlsh his curios1ty, never be in haste to satisfy 1t....... Let him know nothing because you have told it to him, but because he has comprehended it himself; he is not to learn science, but to discover it; if you ever substitute in his mind authority for reason, he will no longer reason....." 1. Harap, Henry. The Technique of Curriculum Making,

2. Rousseau. E'mile, (Translated by W.H.Payne, Appleton, New York, 1914.), pp. 54, 8, 9, 29, 24, 184. 
There 1s an ultra-radicallsm in Rousseau's educational principles that seems to be exemplified in certain contemporary activity schools. Walden School, of Now York 1s such a school. Miss Margaret Naumberg who founded the school about fifteen years ago, under the name of the Children's School says, "From its inception the Walden school has belonged to the chlldren. An attempt was made in the beginning to break the traditional formality of school interiors by developing an intimate and child-like atmosphere." I It is sald to represent the extreme typo of child-centered school.

Pestalozzl and Froebel, Rousseau's Immediate followers were definitely influenced by his theories, although they sensed a certain difficulty in their practice. ${ }^{2}$ The development of the "natural" child took no account of direction. He was ungulded and entirely unhampered. Pestalozzi discovered the need of modification when he attempted to bring up his young son according to Rousseau's principles. Ho found that the theories "would need much modification in practice and rightiy concluded that the most natural environment for a child was a home dominated by the spirit of strict but loving discipline." 3

1. Naumberg, Margaret, and others. "How Ch1ldren Decorate Their Own School", Creative Expression Through Axt. Progressive Edrcation Association, Washington, D.C.p. 163. 2. H1ssong, Clyde. The Act1vity Movement. Warwick and York, Inc. Baltimore, pp. 31-2 1932.

3. Duggan, S. P. A Student's Textbook in the History of Educat1on. New York: Appleton. p. 226. 1927. 
Froebel combined in his educational phllosophy "the naturallsm of Rousseau, the 1deallam of philosophers, the romanticism of the poet, the myaticism of the Christian, and the aspirations of humanity." 1 He adrocated selfactivity, creative expression, social participation and strongly emphasized the value of education through play and motor activities. He pointed out the seriousness rather than the triviality of play and emphasized its value as a froeing agency.

Pestalozzi and Froebel modified the extreme radicaliam of Rousseau, although his imprint was clearly seen in their educational policies. Their contribution to modern education was outstanding. Pestalozzi emphesized the part the home plays in the education of the whole child. In this there is agreement with modern educators who hold the school, the home, and the community equaliy important in integrating the child.

Froobel made a defintte contribution by his interpretation of play and motor activities in education. This emphasis upon the educational value of play has reached an important place in modern education. Meriom ${ }^{2}$ has recently published

1. The Th1rty-Th1rd Yoarbook. Op. c1t., p. 15.

2. Meriam, J. I. "An Activity Curriculum in a School of Mexican Children", Journal of Exporimentel Education, 1 :309-15; June, 1933. 
a study of an Activity School for Mexican Children, near Los Angeles, California. The curriculum in this school consisted of three subjects: play, stories, and handwork. It is interesting to note the use of the word "subject", in that play was considered a subject in this curriculum. Herbart followed as an interpreter and critic of Pestalozii. He was much concerned with instructional methods and materials, and was an exception to the group stressing natural development, although he did emphasize interest in education and objected strenuously to knowledge introduced under compulsion. 1

Herbart's philosophy was embraced, interpreted, and adapted by a great number of enthusiastic followers. Of these, Ziller was responsible for the development of the culture epoch theory. "2 This theory "provided a way of guiding natural tendencies by discovering their origin. Because of biological investigation supporting the recapitulation theory and the advance of the theory of evolution, many believed that the development of the child must be similar in character." 3

It is rather interesting to note that this culture epoch theory after having had very little effect upon the educational practice of those following Ziller, has been revived by Ferriere and has become the basis for his operations. 4

I. The Thirty-third Yearbook. Op. cit., p. 16.

2. Hissong, Ciyde. The Activity Movement. Op. cit., p. 35.

3. Ibid., p. 35 .

4. Ferrlere, A. The Activity School. John Day Company, Now York, 1928. Chapter II. 
He compares the evolution of the individual with the evolution of mankind and points out their parallelism from the earliest stage of tactile sensation in the savage to the highest type of development, which he classifies as thinking in the scholar. ${ }^{1}$

Hissong opposes emphatically this theory for the establishment of an activity school. He says:- "The activity school, built upon the idea of the importance of the growth of the child in a rich and varied environment, cannot subscribe to the culture epoch theory upon which Ferriere has built his modern school, for this consideration of environment in light of its possibilities of emphasizing racial development, directly limits the child's range of experiencing. If the child is provided material in order that he may have appropriate activity for each racial period, his freedom must be limited by such experience as is suitable for the development of the major emphasis in each period. He cannot experience unbounded vicarlous living." 2

Herbart's contribution to the modern activity school movement represents an entirely different phase of emphasis than that of his predecessors. He was concerned with mind activity rather than physical activity. Certainly his doctrine of interest in education had far-reaching

1. Ibid., p. 110 .

2. Hissong, Clyde. The Activity Movement. Op. cit., p. 43. 
effect upon his followers. He held that "to realize the final aim, a nearer and another one must be set up..... Many-sidedness of interest...........Mere information does not suffice; for this we think of as a supply or store of facts which a person might possess, or lack, and still remain the same being. But he who lays hold of this information and reaches out for more, takes an interest in 1t. Since this mental activity is varied, we need to add the term 'many-sided'."I

If Herbart's instructional methods seem formal to modern educators, there is still a definite debt due him for his doctrine concerning the cultivation of many-sided interest.

Certainly the present day activity movement owes a recognizable debt to the thinking of these leaders of a former day in their reaction against formalism in education. The roots of the activity movement took hold of progressive educators as far back as the Renalssance period.

To these fearless thinkers, centuries ahead of their time, modern educators pay homage. Present day principles of growth through real life situations, development of the whole child, purposing, planning, creating, and activating all these had their counterpart in an earlier day.

1. Rein. Outlines of Pedagogics. (Translated by C.C. and I.J. Van Liew. Kellogg, New York, 1893), p. 101. 
II. The Activity Movement in America

Franc1s W. Parker is generally conceded to be the pioneer of the progressive education movement in America. ${ }^{I}$ As the director of the Cook County Normal School in Chicago, he "worked out, put into practice, and taught to his teachers a theory of education along the lines which Pestalozi and Froebel had developed, of making native endowment of the child rather than the curriculum, the center of attention on the part of the educator." 2

It was John Dewey, however, Professor of Philosophy and Head of the Department of Education at the University of Chicago from 1894 to 1904, who was responsible for the actual crystallization of the movement in his "child growth" philosophy, so well expressed in his books, School and Soctety and The Child and the Curriculum. ${ }^{3}$

In 1896, Dewey, in company with a small band of colleagues, opened a laboratory school on the campus of the University of Chicago. Its beginning was modest - an appropriation of three hundred dollars was the maximum allowance for its initiation. 4 A house on the campus was utilized but the

1. Hissong, Clyde. The Activity Movement. Op. cit., p. 1.

2. Cobb, Stanwood. The New Leaven. John Day Company, New York, 1928. p. 10 .

3. Hissong, Clyde. The Activity Movement. Op. cit., p. 1.

4. Clapp, Elsie R. Lectures, University of Louisville, 1934. 
pupil enrollment increased so rapidly that it was necessary to move four times in the first four years to accomodate the overflow.

The school was set up to test certain 1deas about education. Dewey's cornerstone was the doctrine of growth and activity. He insisted that school subjects must be developed out of the children's "life activities"; that living and learning were inseparable and that the life of the school must be active and not passive. To this end he planned his curriculum around four chief Impulses: the social instinct, the expressive instinct, the art instinct and the instinct of inquiry. ${ }^{1}$

With the help of his teachers, the findings of growth and development were carefully recorded. ${ }^{2}$ Fixed distinctions were ridiculed, analyzed and exploded. The attltude of those in the school was that of re-examination of methods and experimentation for improvement in actual doing. The growth of the children was considered of prime importance and great stress was placed upon the discovery of what conditions were most favorable for learning. The term "growth" was held to be all inclusive, combining and interpenetrating mental, physical, emotional and social angles. The child

1. Dewey, John. School and Society. University of Chicago Press, 1899. p. I1.

2. Clapp, Elsie R. Lectures. Op. cit. 
was considered as a whole.

In 1904, Dewey severed his connection with the University of Chicago and became Professor of Philosophy at Columbia Uniyersity. "From that time on, he turned to the task of phrasing the educational philosophy for American democracy. He created a new educational theory for the school - a rationalization of the changing industrial, political, and social situations. He synthesized the generalizations of the new biology, chemistry, physiology and psychology. He carried on the James tradition in philosophy."I

Shortly after Dewey's school closed, J. L. Meriam established a small laboratory schoolat the University of Missouri. He experimented with a radical curriculum and, like Dewey, held to the theory that education should draw out the possibilities from within the child and under no circumstances impose from without.

Francls W. Parker, to whom reference has already been made, opened a laboratory school in Chicago, in 1901. The faculty of sixteen members was placed under the leadership of Flora J. Cooke. Practically all of these teachers had been associated with Colonel Parkex in the Cook County Normal School. 3

Like the Dewey and Meriam Schools, the curriculum was

1. Rugg, Harold, and Shumaker, Ann. The child-Centered School. World Book Company, New York, 1928. p. 40.

2. Ibid., p. 41 .

3. Ibid., pp. $42-43$. 
organized "around concrete activities which were chosen in terms of pupil needs and personal development." I Parker made much of individual growth through membership in a social group. In The Social Motive in School Work, he says: "In the atmosphere of freedom and responsibility surrounding these social enterprises, self-control and other moral qualities are developed through the demands for them. The narrow consideration of self is pushed to the background for the welfare of the project, since the child himself realizes that he must work in the place where he can work best. The judgment of the group is nearly always just, and no examination marks, no artificial rewards or praises, can equal it as an incentive to good work." $\stackrel{?}{2}$

Holding to its belief in self-actuated work, training In Infiative, child interests, real experiencing, creative expression, individual development as opposed to group development, and the social motive, the Francis W. Parker School has contributed for twenty-five years to the "child growth" movement. 3 With Dewey, Parker is generally looked

1. Ibid., p. 43 .

2. Francis W. Parker Studies in Education, Volume l, The Social Motive in School Work, 1912. p.13.

3. Ibid., p. 11 . 
upon as one of the gulding lights in the establishment of the child-centered school.

With the exception of the Meriam and Parker Schools, no experimental school appeared for at least ten years after Dewey's departure from Chicago. Then a veritable mushroom growth of schools appeared and each year sees a new crop. ${ }^{1}$

Meanwhile, William H. Kilpatrick published, in 1918, a monograph, The Project Method. This, in addition to his lectures at Teachers College and his later writings did "more directly to transform the attitudes of teachers and administrators than the more obscure methods of his predecessors in philosophical thinking. "2

The influence of these educational "revolutionists" has been far-reaching. Progressive education is not confined to the United States alone. Schools have been established in South America, Europe, Africa, Australia in fact, all over the world. 3

In the United States, activity schools are found in all sections of the country. Among the more outstanding are: the school at Columbia, Missouri, of which J. L. Meriam

1. Clapp, Elsie R. Lectures. Op. cit.

2. Rugg, Harold, and Shumaker, Ann. The Child-Centered School. Op. cit., p. 47.

3. Clapp, Elsie. Lectures. Op. cit. 
was formerly head; Marietta Johnson's School, at Fairhope, Alabama; Ethical Culture School, New York City; The Modern School, Stelton, New Jersey; Moraine Park School, Dayton; Park School, Buffalo; Beaver Country Day School, Chestnut Hill, Massachusetts; Helen Parkhurst's Dalton Schools, New - York; Chevy Chase Country Day School, Washington, D. C.; Walden School, New York; and the Lincoln School, New York. I

In addition to those mentioned, scores of other schools of equal merit could be listed. What is impossible to list, however, is the vast number of school teachers who have "caught the gleam" and are vitalizing classrooms all over the country by this newer conception of education. Even if this development is not uniform, granting the errors and mistakes, st1ll we would say that the greatest hope for freedom, purposeful endeavor, and initiative lies in the fact that individual teachers may reproduce in their classrooms situations at least approximating the ideal.

1. Thirty-third Yearbook. Op. cit., p. 40 . 
CHAPTER II

PHILOSOPHICAL, PSYCHOLOGICAL, BIOLOGICAL AND

SCIENTIFIC ASPECYS OF THE ACTIVITY MOVEMENT 


\section{CHAPTER II}

\section{PHILOSOPHICAL, PSYCHOLOGICAL, BIOLOGICAL,}

AND SCIENTIFIC ASPECTS OF THE ACTIVITY MOVEMENT

In the effort to gain deeper insight into the basic principles of the activity movement, the philosophical, psychological, biological and scientific elements will be considered. In considering these aspects, certain educational implications will be pointed out.

\section{Philosophical Elements}

Childs, I in discussing the philosophy underlying the activity movement, points to the experimentalist's opinion that "all ideas, beliefs and ideals grow out of, and relate to, concrete experiences." He holds that the mind is not a ready-made structure, developed by formal disciplinary exercise. It is, rather, the result of a process of experiencing or living. Since difference in environment causes difference in experience, it follows that it would also cause a difference in mind. "The individual is a product of his own activity just as truly as he is a product of the social influences which nurture his mind."

1. Childs, John L. Education and the Philosophy of Experimentalism. The Century Company, New York, 
In using the term "experimentalism", Childs explains that "it refers to the general body of philosophic thought associated with the names of Plerce, James and Dewey." I He chose the term instead of using the more widely known "activity movement" or "progressive education", because of its significance in construing life and knowledge. He points out the relationship between this philosophy and the ordinary world of human experience in that it gathers its intellectual materials from concrete conditions. The physical and social environment must be studied to fully comprehend its development.

In considering these two aspects, Childs points to certain social factors which he believes are at least partly responsible for conditioning the thought of the experimentalists:

1. The youth of the American Republic as compared with European countries and the consequent lack of the hampering influences of tradition, customs and institutions.

2. The fluidity of frontier life and its influence upon the pioneer as compared with the rigidity of life in settled regions of Europe.

3. The influence of natural resources upon social democracy and human progress.

1. Ib1d., pp. 6, 11 . 
4. The more recent influence of sclence and industry upon the development of the United States. In considering the basic principles of the philosophy of experimentalism, it is easy to see how its conception of experience, knowledge and social implications links it closely to the philosophy of education. The creed of the experimentalist is that "Ilfe should be a continuous process of growth through learning from experience." I He looks to the schools for the development of habits and attitudes conducive to constant learning from experience.

The educational implications of this point of view are important: ${ }^{2}$

1. It involves a shift in the basis of authority.

2. It calls for a testing of beliefs, customs and moral codes in the light of their consequences in ordinary Iife experience.

3. It discards the idea of absolute certainty and fixed rules, because of the changing process of experience. 4. It calls for hypotheses rather than dogmas and demands modifications of these hypotheses as experience alters.

5. It challenges the schools to equip students to experience on an experimental basis.

6. It impels a new conception of nature and of man in the light of present social and scientific knowledge.

1. Ibid., p. 43. 


\section{Psychological Elements}

In considering the psychological aspects of experimentalism, it is necessary to examine the great diversity of viewpoints and the variety of psychological principles held by conflicting schools of thought.

These differences were effectively brought out in the deliberations of the various lecturers at the Fifth World Conference of the New Education Fellowship held at Elsinore, Denmark, in August, 1929, on the subject of New Psychology and New Education.

During the course of the Conference, the following psychologies found expression: "(1) Individual psychology, emphasizing difference in mental types; (2) the psychology of Individuality, represented in their different ways by Montesorri and Nunn; (3) an American psychology, compounded of behaviorism and pragmatism; (4) the Gestalt psychology, and a related psychology of wholeness; (5) psycho-analysis of the Freudian order; (6) a psychology of irrationalism, going back to Nietzsche, expounded by Welsmantel."I

In discussing these various stands, Boyd has pointed out that this diversity of opinion need not be viewed with alarm. Neither should a premature synthesis be made, according to his judgment, because of the possible danger

1. Towards a New Education. Edited by William Boyd for The New Education Fellowship. Alfred A. Knopf, New York, 1930. p. 348. 
of losing valuable "ideas". He feels that there is a promise of a unifying view in a consideration of the lectures as a whole, in that "on a survey of all that was said, it seems possible to see the emergence of one dominant idea as the characteristic principle of new educational thought and practice, in the stressing of the whole as always greater than and different from the parts." I

Childs concurs with Boyd in this view. ${ }^{2}$ He points out that a significant "conflict in psychology today is about method and what should be taken as the elemental unit for psychology." He suggests "the complete unit of experience as the foundational element." He cautions against the inevitable confusion which results from a separation of the child and the environment. If either behavior or environment is treated as a determining factor an abstraction results which is misleading and confusing.

This same principle of wholeness is expounded by Raup. 3 He points out four characteristics illustrative of a general change in the psychological outlook:

1. The new education insists that the learner must be studied as a whole being if the most desirable values In Iife are to be conserved.

1. Ibld., p. 348 .

2. Childs, John L. Education and the Philosophy of Experimentalism. Op. c1t., pp. 73-74.

3. Raup, R. B. "Is There a Psychology of Wholeness?", Towards a New Education. Op. cit., pp. 398-410. 
2. The creative factor in living and learning is a vital note in the new education.

3. The dominance of the present rather than the future In the life of the learner is emphasized.

4. The new education demands a social psychology for the fuller understanding of the behavior of groups. In summarizing these points, Raup emphasizes the importance of the psychological movement which he calls "the psychology of wholes or whole-events." He reiterates the belief of Boyd and Childs that a "whole event in the course of living experience knows no essential separation between environment and the organism. No form of activity can be conceived properly as belonging now to the one and now to the other." 1

Brim, in considering the psychological side of the activity movement, takes his stand with those who think in terms of the whole child. He says, "The whole child is not a fiction. Multiple learning is a fact. The effort to Integrate school activities and these with life experiences is but sane psychology." 2

Kilpatrick holds that psychology's best insight into behavior and learning is exemplified in the basic principles

1. Ibid., p. 401 .

2. Brim, Orville G. "Basic Realities and the Activity Movement," Progressive Education, p. 332. October, 1934. 
of the activity movement. He says, "Life is itself an affair of action. The individual, alive and alert, faces at each moment some situation that is making demands upon him and to which he responds with preferences and with efforts as an organized whole to attain these preferences." Since it is agreed that learnings are never single and that it is impossible to parcel out any one factor for specific training, significant educational implications become apparent:

1. The school must recognize that habits, purposes and ideals are being formed constantly in the daily experiencing of the pupils.

2. Children learn by practice - therefore schools should provide adequate bases for practice in experiencing.

3. Active experiencing and not isolated learning must be the procedure if the school is to make use of psychological findings.

1. Kllpatrick, W. Thirty-third Yearbook. Op. cit., p. 200. 
III. Blological Elements

If the psychologist has pointed the way to the new education, the biologist has been none the less helpful. Childs says that "the experimentalist sees man as an organism in continuous interaction with its environment." I He points to behavior, which he calls activity, as the most characteristic thing about life. He shows that the analJsis of any organic activity discloses itself both as a function of the environment and a function of the organism. For instance, breathing included air as well as lungs; eating involves both food and digestive apparatus. Habits and acquired responses may be included in this reasoning; for example, swimming necessitates water as well as the movements of the arms and legs of the swimer.

This recognition of the continuity of organism and environment is the foundation for the experimentalist's challenge of many current educational practices. He attacks that procedure which "assumes that the individual child is an isolated unit so completely self-enclosed that he can be treated entirely apart from the environment which actually penetrates his every act and thought." 2

In further discussing this interaction as the primary fact in all experience, Childs explains the effort of the

1. Childs, John L. Education and the Philosophy of 2. Ib $\frac{\text { Experimentel }}{\mathrm{id}}$. 71 . 
organism to maintain life by effecting an equilibrium with the forces of the environment. Constant adjustments are necessary which may be secured by changes in the organism, the environment or both. The formation of habits is described as a result of bullding into the structure of the organism those responses which successfully reduce difficulties. 1

He considers experience as "an active process of doing and undergoing and not primarily a cognitive affair. The knowledge experience is only one form of experience..... Primary experience is not an affair of knowing; it is esthetic in quality, a matter of 'being and having', of 'doing and undergoing', of'suffering and enjoying'". 2 Nunn, in discussing basic principles of experimental education, makes an analysis almost identical to that made by Childs. 3 He points out that the child must not be thought of apart from his environment. He cites J.S. Haldane who says that the fundamental characteristic of a living creature is its dependence for existence upon active and perpetual intercourse with its environment. Nunn holds that "the new education thinks of the child's life dynamically as a process of give and take between

\footnotetext{
1. Ibid.,p.72.

2. Ibla., p. 78 .

3. Nunn, T. Percy. "The Basic Principles of the Hew Education", Towards a New Education. Op. cit., pp. 455-456.
} 
him and his environment, and consequently of the work of the school as primarily to supply an environment containing the elements deemed necessary for the best types of human growth. "l

In considering these biological aspects, certain conclusions may be drawn in relation to education:

1. The school is worthwhile only in so far as it is capable of producing an environment where experiences are truIy educative.

2. Purposeful activity is the only solution for satisfying experience in a world of change. By purposeful activity is meant such an activity as may be initiated in response to challenging difficulties in the child's present experience.

3. Since conditions change and experience goes on, the school must use the present and not the past as a criterion for evaluating principles.

1. Ibid., p. 78 . 


\section{Scientific Elements}

Much of the foundation for the scientific and experimental attitude which has marked so definitely the newer trends in education, was laid in the latter part of the nineteenth century. A widespread interest in natural science, "with which the names of Huxley and spencer are most prominately associated, accentuated the emphasis placed both on sensory motor experience and logical thinking as the bases of education........the nineteenth century witnessed a series of radical and profound changes in both the theory and practice of education........The beginnings of scientific child study were well established."I

It remained, however, for the educators of the twentieth century to attack, expand and develop the experimental study of children and place it upon a scientific basis. 2 The influence of our technological civilization, with its attendant incorporation of scientific principles and procedures was felt in the educative process. Especially was this true of the experimentalist in education. Machines, he reasoned, were developed through experimental procedures. 3 They are in a constant state of adaptation,

1. Darsie, Marvin L. "The Philosophic Origins of Progressive Education", School and Soclety. p. 419. September 30, 1933.

2. Ibid., p. 420 .

3. Childs, J. I. Op. c1t., pp. 35-36. 
modification and improvement. If these procedures could so adequately extend man's control over his environment, why could they not produce similar results in the social and moral realm?

The experimentalist, however, while proceeding upon this theory of scientific approach to difficult problems, does not agree with those who hold that science has actually reduced the uncertain, hazardous elements in human existence. He grants that practical science has reduced in great degree the struggle for bare existence with which man was formerly confronted. However, he points to the present social maladjustments to prove the precarious nature of modern civilization. ${ }^{1}$

He is challenged rather then daunted by the universality of change. It is his fundamental basis for the rejection of all absolutes, finalities and fixed principles. He sees nature as "a moving complex scene of individualized, qualitative events." 2 He sees these events linked and influenced in various ways by other events. In fact, he accepts life as a process and shapes his thinking around the factors he finds in experience.

Brim suggests the same line of thought when he points to sclence as a freelng agency. ${ }^{3}$ He credits it with

1. Ibid., pp. 62-65.

2. Ib1d., p. 116.

3. Brim, Orville. op. cit., pp. 331-332. 
releasing man from the domination of super-mundane powers and revealing to him a world of law. It not only freed man, but fixed upon him the responsibility for working out his own destiny. In releasing man from intellectual slavery, science has challenged the school. Educators must strive to develop self-direction rather than the old obedience if scientific concepts are to function.

Significant conclusions may be drawn from those scientific aspects for education:

1. The schools must recogntze rapid change and the uncertain future.

2. The schools must "educate" rather than "indoctrinate", that is, fixed beliefs and knowledge must be replaced by analyses of changing situations through intelligent understanding.

3. The schools may perform their greatest service by teaching how to think rather than what to think.

\section{Summary}

Reviewing the various aspects of the related sciences Indicates that certain principles, basic to philosophy, psychology, biology and science are likewise foundational to progressive education.

The principles of growth, change, experience, continuous development, freedom, initiative and activity are not 
isolated factors. They function significantly in Iife as well as in education, in fact, they are life, and as such, demand consideration in the school.

In setting down the educational implications of the philosophical, psychological, biological and scientific aspects of experimentalism, it has been impossible to draw definite lines of demarcation. Overlapping exists, but this same interrelationship may be seen throughout and in this lies its greatest value. 
CHAPTER III

TRACING AN ACTIVITY PROGRAM

IN

ONE PUBLIC SCHOOL 
TRACING AN ACTIVITY PROGRAM IN ONE PUBLIC SCHOOL

Adams defines an activity as "any learning situation which meets the natural interests and felt needs of children and leads to better adjustments than did the traditional school organization."l With this definition in mind, it is possible to see the beginnings of an activity program in the Nicholas Finzer school as long as twelve or more years ago. While these early efforts cannot be called "activities" in the strictest sense of the term nor the attempts called a "program", certainly, beginnings of our unit type of teaching were present.

It is the purpose of this chapter to point out these evidences of activity wherever they were found in the school. Since these instances were the exceptional rather than the uniform procedure, their recounting may appear to lack coherence. However, an effort will be made to show how the influence of progressive practices, in seemingly isolated situations, eventually permeated the whole school.

It is necessary to recall, briefly, the teaching program of 1923 in order to get a clear picture of progress from that time to the present. The typical elementary

1. Adams, Fay. The Initiation of an Activity Program into a Public School. Bureau of Publications, Teachers College, Columbia University, New York, 1934. p. 3 . 
school of that day consisted of a kindergarten and eight grades, with a departmentalization of the sixth, seventh and elghth grades. The program pigeon-holed the child's day into thirty minutes for arithmetic, fifteen minutes for spelling, twenty minutes for language and so on. Subjects were compartmentallzed and curricula were generally inflexible. Even in the primary grades, time allotment in subject matter divisions were of predominant concern. Our first attempt to break down this rigid separation of subjects was made in the departmental grades. The incentive was the eighth grade "commencement" - a designation given the exercises which marked the completion of elementary school work. It was suggested to the children that it might be interesting for their parents and friends to see the work that they had accomplished in the 8 a grade and hear their reports of it.

With this thought in mind the 8 a children spent the major portion of their final semester in working out a unit to be presented in some form for their parents and friends at the close of the term. This "commencement program" as the children called 1t, became an institution, and they discussed possible topics even before they became 8 a students.

Each of the six teachers responsible for teaching the children had a part in the execution of the unit, but the teacher whose subject represented the major interest was 
responsible for directing the unit. For instance, if the subject matter emphasis was upon English, the English teacher planned the procedure with the group and delegated the responsibility for related subject matter to the teacher of that subject. An effort was always made to choose a unit in which as many subjects as possible could be correlated. The choice of the subject was made by the children with the help of the teachers. In looking back, however, over the variety of subjects utilized, the question arises as to how much of the choice lay with the children.

A description of one of the earlier units worked out on this plan will be given to show how a unification of subject matter was effected.

This particular 8 a had always been interested in nature study. They had made collections of autumn leaves, flowers and shrubs, rocks and shells to show color in nature. Their home room teacher used this interest to direct their attention to color in other fields. They soon decided to use this subject with all of its ramifications for their 8 a unit study.

This was the type of unit that we liked to work out because of its great possibilities for correlation. The English teacher guided the study of color in literature. The children read poems, stories and descriptive passages to find words expressive of color. Each child kept a word list in his notebook and once a week the most colorful 
words were written into a class book.

In the history class, the natural sources of color were determined. In so far as possible, books were put at the disposal of the children so that they could find for themselves that the indigo plant grew in the Nile Valley more than five thousand years ago; that Tyrian purple was secured at great cost from a species of sea snail found in the Hediterranean and that ultramarine was actually made in the eleventh century in Asia by grinding species of the precious lapis-lazuli stone. In the search for sources of color, the children came across such interesting accounts of colored stones, both synthetic and precious, that they asked if they might include jewelry in their historical summary. Since this was the type of investigation which we were so anxious to secure, the suggestion was enthusiastically received and the children were told to bring to class for discussion any correlated lines of 1nterest. Whenever such a suggestion was brought in, it was discussed from the standpoint of acceptabliity to the class; greater enrichment of the unit; availability of source material for its study; and general worthwhileness for inclusion in the program. It was accepted or rejected by the class on these bases.

The science teacher took groups to visit the Kentucky Color and Chemical Company to see the process of making powdered pigments, and to Kurfees' Faint Company to see 
these pigments mixed to make colored paints.

The art teacher considered color printing from the standpoint of its value in advertising. The Standard Printing Company was visited to see the process of color printing. The children used the advertising principles in making charts and posters for use in the final program. They discussed the relative desirability of certain color combinations from the standpoint of force, attraction, beauty and carrying quality. They made rough designs and experimented with them in other classes to test for these qualities through childrens responses.

Color symbolism and its relation to every day life was another point of departure in the art room. Appreciations were developed through discriminating choices of color. Opportunities were provided for flower arrangements in the schoolroom. Principles of color harmony were discussed and certain simple guides to pleasing combinations were evolved. The same idea was carried out in costume design. The children experimented with different color combinations to secure pleasing effects in costume.

Pictures were used to show how these same principles were carried over into the home, the shop, and the theatre. The music teacher conducted an experiment to test what, if any, color responses were aroused when widely different musical selections were played. For example, children were asked to write down what emotion was felt when certain musical selections were played. The words were written 
on slips of paper and children were told to check against any word which expressed their feeling or if nothing was felt to make no marks. Some of the selections used were: "Morning", "March from Tannhauser," Chopin's "Funeral March", and Paderewsk1's "Minuet".

Protective coloration in nature was used by the geography teacher to illustrate the security of the natural environment for birds and animals. She initiated the study by the recall of much reading that had been done by the class on the subject of man's ability to protect himself agalnst the environment. The question was raised, "What do birds and animals do?" "How can they protect themselves?" Discussion brought out that animals (excepting domesticated. animals) must protect themselves against man, and in this way they are alded by nature. A colored picture of an Arctic tern, snowy white, large but almost invisible againgt its background of snow and 1ce, was shown to the children. Through this lead, the study was launched. The search for pictures and source material on the subject of protective coloration brought to light so much that was of interest to the children that the regions introduced, covered the world in span. The geographical ramifications were amazingly wide. The study included:

1. Climate, temperature and rainfall.

2. Vegetation, with the attendant problem of food. 3. Surface conditions of the various countries. 
4. Bird routes (traced on map).

The attitude of inquiry was present constantly. There was so much of the "why" and the "how" in their minds. How could birds travel such long distances without rest? How did we know that this was true? Why did birds fly in certain formations?

They were guided in their search for solutions by the classroom teacher and by Miss Yunker, the Supervisor of Gardens and Nature Study in the Louisville Public Schools. Certain valuable books were made available for reference through the courtesy of friends of the school.

These children were very anxious to make something for their commencement which would show the magic of this merging of the birds' color into the background of his environment. After much discussion, planning and experimentation, they hit upon the idea of making habitats in sand trays and making birds to fit these habitats. They showed great ingenuity in perfecting these. Birds were made of papier mache' and painted in their natural colors. The environment was shown in the sand tray. Grass, twigs, flowers and branches were used to make a life-like habitat. In the case of the tern, which fascinated the children, and which they insisted upon reproducing, cotton and glazed paper were used to simulate the snow and ice of the Arctic region. A background was painted to further characterize this setting. This particular phase of the unit was rich 
in its opportunities for problem solving, creative expression and subject matter integration throughout.

From all of this color work a program was evolved for commencement. As has been indicated, this was the real purpose for the execution of the unit.

The explanation of this procedure has been given in some detail because for several years to follow, all 8 a units were worked out on this same plan. It should be noted, however, that this organization was used only in $8 a$. In the other departmental grades - $6 a, 7 b, 7 a$, and $8 b$ - the regular history, geography, English, science, and mathematics courses in their unrelated aspects were used.

It will be seen that mathematics did not enter as a part of the correlated work in the color unit. This was usually true of any unit that was chosen and so the regular course in mathematics was followed rather consistently. The question may arise as to how the other prescribed work fitted into this program. The English teacher had just as great opportunity in unit teaching as otherwise for written and oral expression. Letters always needed to be written asking for permission to visit, and thanking for the visit upon return to school, information secured on trips had to be organized and reported, discussions always preceded and followed excursions, and talks had to be prepared for the final program. 
The art and music presented no problem because of the greater fluidity of these courses of study.

The science, history and geography presented the greatest problem from the course of study content side. Our usual procedure was a compromise in these situations. Often the unit chosen showed less emphasis upon science or history and geography than upon English. In this case, as much time as was necessary for the correlated teaching was given and then the regular course of study resumed. If the emphasis of the unit centered largely upon any one of these subjects, we tried to adjust the schedule so that more time could be given, and in this way the required course of study material be presented. One great help in this adjustment was the attitude of the children. They were so anxious to work on the commencement program that they were willing to give up study periods, come before school in the morning or take extra home work assignments to make up the1r "regular work".

Since the unit always set up problems to be solved, certain habits of work and study were developed that aided tremendously in attacking and completing the isolated subject matter course that we felt obligated to consider.

From the standpoint of learning, this newer type procedure pointed to certain educational implications: 1. Group participation, with its attendant sharing of 
experiences.

2. Problem solving, with its opportunities for choice, decision and judgment.

3. Unification of subject matter, with its pull away from isolation.

4. Constructional activity, with its opportunities for creative expression.

In making a critical evaluation of this piece of work, it may readily be seen that the weak points outweigh the strong ones. While there was a definite motivation which was especially desirable at a time when subjects generally were pigeon-holed, undoubtedly the project 1tself was superimposed. It is unlikely that the children would have chosen this subject of their own volition. Neither can one be at all certain that it answered a "felt need". Certain phases of the plan bear close scrutiny: for instance, excursions, in a day when these were not considered a legitimate part of the school program and had to be consummated after school hours. The expressional work also measured well up to present day standards. However, excellent opportunities for experiencing were neglected; for instance, in the section where pigments, paints and dyes were studied, the possibility of dyeing materials was entirely overlooked. The greatest value in the study of color is through its use. Mixing, combining and selecting 
colors should have been experienced by all children throughout the project.

In the section on "Color and Sound", the association between color and music, while entirely possible to highly sensitized adults, seems very remote when an average group of children is considered.

The question may arise as to why this same type of work was not provided for the other classes in the departmental grades, especially since the results were so satisfactory In our opinion. As has been pointed out, the Nicholas Finzer School is a public school in a large system, and any wholesale departure from accepted practices would not have been tolerated. In the endeavor to make an opening wedge, the elghth grade seemed the logical one with which to experiment because the motive was so vital to every child. Moreover, the parents were so enthusiastic over the final program with its resume' of accomplishments that they registered satisfaction rather than opposition to the freer type of work.

In the other grades of the school, Ib through $6 \mathrm{~b}$, each class is under the direction of one teacher. At this time therewas little in the way of activities in the broader sense, seen in the school. Both intermediate and primary grades adhered rigidly to a time schedule and subjects were fitted into the compartments of the schedule. Drawing, music and industrial work, as it was then called, had no 
more relation to other subjects than had arithmetic. Th1s rigidity was probably less true of the early elementary grades than of the intermediate, however, as the influence of the kindergarten has always had a liberalizing effect upon the first grade. Then too, the younger children are naturally more spontaneous in thought and action than those of the intermediate groups. Even traditionally, more freedom has been countenanced with the little children. They have more generally explored the neighborhood and enjoyed life experiences. However, these experiences were incidental rather than foundational. They did not unify the reading, language, spelling and expressional work. The course of study had to be followed and life experiences were not a part of it.

During the years, 1924 and 1925, the teaching of health gained impetus in the schools. "May Day - Child Health Day" was generally sloganized. There seemed to be an opportunity to use this new interest for integrative purposes in the school. A health pageant was decided upon for a May Day program.

A faculty meeting was held early in the semester when plans were laid. Each class was to contribute an episode based upon the results of the health work carried on during the term. By this procedure, the course of study requirements were fulfilled, yet each teacher was challenged to 
produce some result which would be acceptable for a unified program. Since there was much subject matter overlapping in the health outlines for the various grades, meetings were held and committees formed to organize the program. This was not done, however, unt1l all possible contributions from each class were listed and considered. This listing brought into play real thinking on the part of the children. It was necessary for them to suggest the type of program which they desired. They were encouraged to think of as many types as possible. All suggestions were taken and Iisted on the board. Then each suggestion was welghed and considered in the light of its advantages and disadvantages. Would the idea lend itself to reproduction in a program? How many children could participate? Could the necessary materials be secured? Was the end-result interesting? Would it be a worthy summary of a semester's work?

By this method of critical evaluation, the list of suggestions was usually reduced to two or three likely problems. Of these the class selected the most desirable.

This procedure was consistently followed throughout the entire preparatory period. Problems arose constantly. For instance, since the program was to be given in the yard, the question of whether the audience could see and hear was constantly in mind. Was the lettering on the 
slogans large enough for all to see? Were the color effects pleasing from a distance? Did the speakers enunciate clearly enough for the audience to hear them? Was the content of the episode clear and definite enough for the audience to grasp the meaning?

These are but a few samples of the great variety of problems which demanded thinking and judgment on the part of the children, and here-in seems to have lain the greatest value of the activity. When the program was finally perfected, not only each class, but also each child in the school had a part. This necessitated a large number of drills and rhythms. For instance, when one class wished to emphasize the value of fresh air in the room of a sleeping child, all those not actually participating in the dramitization of this episode, became fresh air sprites dancing about the stage. When another class told about the importance of fresh vegetables in the child's diet, every child not actually speaking, became a vegetable for the background.

Since the school has no auditorium, all efforts to unite the school become problems. The halls are narrow and no two rooms may be thrown together by raising blackboards as is often the case in old schools. The yard offers our only solution. It is inadequate and unsatisfactory, but the only possibility. Consequently, the jard was used 
and several hundred parents, friends, neighbors and invited guests formed an audience which stood against the fence, since there was no way of providing seats for more than a very few.

Certain significant educational outcomes grew out of this project. In the first place, the health teaching was vitalized. In going from room to room during the preparatory period, it was easy to see how the abstract qualities of air, water, sunshine and the like were becoming actual, through the child's interest in the dramatization, the story or the song in which these elements figured. Even more significant was the effect of this creative work upon the children. They were less satisfied with the more formal work. This dissatisfaction on their part became a powerful factor in awakening teachers to a consideration of activity versus subject matter learning.

Then, the preparation of these episodes demanded an integration of subject matter in each room. Posters were made to advertise the pageant and placed in the halls of the school and in neighborhood stores. These provided great opportunity for ingenuity and creativeness in design and in the message they were meant to convey. Charts and placards used in the final performance demanded neatness of execution and skill in lettering. Costumes had to be planned and these opened the way for a study of pleasing 
color effects and the reasons for choosing certain colors. For instance, why green was chosen to portray rest; yellow, for sunshine; gray, for rain, and so on. The same type of integration was true of the music. In the departmental grades, where one teacher taught music to the sixth, seventh and eighth grades, an interesting experiment was carried out in two classes. The children made their first attempt at writing the words and music of a song, to be used, of course, in the final performance as a contribution from the music department. In the other grades, where each teacher taught the music to her own class different results were seen. Some classes wrote original words to songs already in their repertoire, and other classes searched for songs, new or old, which best expressed the mood of their episode.

Both teachers and children were guided in the execution of the drills and rhythms by Miss Caroline strubel, at that time Assistant Supervisor of Physical Training in the Louisville Public Schools. Miss Strubel recognized the opportunity for Integration which the pageant offered in her subject. She not only made application of much course of study material, but also suggested possibilities for creating rhythms which were more sultable to our purpose. The making of the costumes was rich in unifying features. Materials had to be decided upon, selected, purchased and made. Each class was responsible for its own costumes 
with the teacher in general charge. It was interesting and significant to note the way in which the different teachers attacked and solved this problem. In certain Instances, the teachers let the children work out and make their own costumes. For instance, dry cleaning bags were painted red and stuffed with crumpled newspapers to represent large red apples. In other cases, especially in the lower grades, excellent cooperation was secured from the home in planning and making the costumes. Mothers came to school and worked with the teachers and children in making the costumes. In a number of cases, however, this opportunity for experiencing was lost. This occurred when the teacher's desire for a finished and beautiful result closed her ejes to the real purpose of the activity - growth for the child through creative experiencing.

In the field of English, integrative factors were readily recognizable. They included the writing of the play, story or feature that the class decided to present; the organization of material secured from various sources; the reporting of this material to the class for acceptance or rejection; the discussion periods in which problems were considered; the writing of letters of thanks to persons who helped in any way; the writing of summaries or reports of findings for future reference, and the writing of invitations to parents, friends and other guests. 
Certain desirable social attitudes were apparently concomitant outgrowths of the whole endeavor. Group participation, cooperation, a community interest in the school, a strengthening of the bond between the home and school through shared experience, a better understanding of the difficulties with which we are confronted, and our adaptation to these existing circumstances.

Throughout this period of time there was a constant and insistent desire on the part of the writer to break down the 1solated teaching situations and develop a more cooperative type of work in which there would be more sharing of experiences. Some excellent teachers were using the most formal methods. It had been hoped that the health pageant would have a carry-over value in showing the Interests aroused by purposeful endeavor. In the majorIty of cases, however, once the incentive was removed, the old type of isolated teaching was resumed. The philosophy was not taking hold.

It seemed then, that the one plan of attack must be through the stimulation of the teachers. Certainly, the writer's personal philosophy precluded any attempt at coercion or authoritarianism. Even formal teaching was preferable to that obtained by superimposition.

With the thought ever in mind that something must be substituted for the lack of an auditorium or meeting place, a little theatre seen in an exhibition at the meeting of 
the Department of Superintendence in Chicago in 1926, offered a happy suggestion. Here was a device, small enough to be moved from room to room, yet large enough in which to give marionette or puppet shows. By placing it upon a box or table in the front of the room, children in the last row could see as well as those in front.

After discussing the idea with the teachers, it was decided to make a theatre for use in the school. A signiflcant fact was the suggestion of one teacher that different classes be allowed to work upon it in the shop so that it would be more definitely a school possession. This suggestion was encouraged, and while the task of actual construction fell to groups of older boys, those in the intermediate grades had a part in the painting and decorating. Older boys again had to care for the more difficult process of wiring. The girls selected and made the curtain. Splendid examples of desirable attitudes on the part of the children were evidenced in the construction of the little theatre. They constantly pointed out that it was "for the school" and so must be made well. The willingness to step aside for the good of the group was a new experience for these children. Opportunities for problem solving presented themselves when the working drawing for the theatre was found to be inaccurate. Since we had sent to Chicago for this drawing, there was no one 
to consult other than the shop teacher, who very wisely made a class problem of it. This very fortunate inaccuracy brought a much larger number into the actual construction problem than would have been possible in any other way. The solving of the problem was effected by dividing the class into groups and letting each group experiment for 1tself. During these experimentations, and later in the actual construction of the theatre, the following operations were necessary:

1. Finding the floor space required for the corrected base.

2. Figuring the necessary height from the floor.

3. Figuring the necessary change in length due to the required change in height.

4. Flguring the required board feet of lumber.

5. Figuring the cost per foot of the lumber.

6. Figuring the required feet of wire.

7. Figuring the cost per foot of wire.

8. Figuring the cost of the completed theatre.

The completed theatre accomplished all that we could have wished. The children were delighted with it and each class wanted to use it. This suggested some necessary type of procedure whereby the children could know when and for what purposes they could expect to use the theatre. The teachers met and discussed what they considered legitimate purposes for the theatre's use. The 
following were suggested:

1. Dramatization of stories.

2. Programs for special days (Columbus Day, Arbor Day etc.)

3. Dramatization of original stories or plays.

4. Health program.

5. Accident prevention program or exhibit.

6. Program for parent-teacher meeting.

7. A culminating program for a unit of work.

Another desirable outgrowth of the use of the little theatre throughout the school was the absolute necessity for creative work before it could be used. Each class had to assume full responsibility for painting the beckground and making the figures needed for the production it had chosen.

This creative work had a real effect upon the penmanship and spelling. Plays, stories and charades were written by the children and developed in the theatre. A real neod arose for legible writing when parts had to be read by children other than the author, which was always the case In the marionette shows. Spelling also was a necessary accomplishment to insure smooth reading. Arithmetic too, was an important feature because scale drawings, usually one-half inch to a foot, were needed in making the background. Children saw in these situations a real need for the skills. 
Attitudes of appreciation and evaluation were developed by allowing the children to choose and decide the relative merits of suggested stories and types of programs which would be presented in the little theatre. Initiative and ingenuity were seen in the making of the figures for the dramatizations. These figures ranged from simple bits of cardboard nailed to sticks, in the lower grades, to marionettes of the most ambitious type in the upper grades.

Oral expression received a great impetus throughout the school, because the theatre required a speaking from behind the scenes instead of the usual facing the audience. This gave a feeling of security to the more timid children and many who had never before participated were now eager to help. Also in the try-outs for parts, much self-consclousness was overcome by the fact that the figures seemingly did the talking.

Since freedom and facility of expression has always been one of the greatest weaknesses of the school, improvement along this line was one of the most gratifying outcomes.

In September, 1927, Miss Martha Kelly, formerly of the Lincoln School Staff in New York, became Primary Supervisor of the Louisville Public Schools. During the sumner of 1927, Miss Kelly conducted classes at the University of Louisville, and two of our primary teachers, Miss Mabel Smlth and Miss Margaret Bennett, were members of these 
classes.

Miss Kelly gave one course in primary methods and another In primary curriculum. It was this latter course which decidedly influenced the thinking, not only of these two teachers, but others at Finzer, who carne into contact with them. Miss Kelly used Curriculum-Making in an Elementary School by the Lincoln School staff as a basis for discussion. This book was not published until later in the same year so the material as used was in manuscript form. The idea of large units, children's interests, purposeful activity and Iffe needs constituted the philosophy in mind, and it may readily be seen how this influence was carried over into the Finzer School.

The following summer (1928), Miss Martha Peck Porter, also of the Iincoln School staff, came to teach in the University of Louisville Surmer School. Miss Lottie Gwaltney, another one of our teachers, was chosen by Miss Kelly, then Primary Supervisor, to be Miss Porter's assistant during the Summer Session. Miss Porter's philosophy of education and her ideas of curriculum were practically identical with those of Miss Kelly, so consequently the work went forward. In this class, the members not only wrote a unit, but actually worked it out from the standpoint of constructional outcomes. They used boxes, orange crates and cartons for creative expression. 
When Miss Gwaltney came back to school in the fall, she put into immediate practice Miss Porter's Ideas and suggestions. She had worked out a community unit during the summer and she used this plan for her second grade class in the fall. Her children explored the community and found it rich in material. Within a radius of eight blocks from the school, it was possible to visit a grocery-store, a drug-store, a florist shop, a fire-engine station, a police sub-station, a branch bank and a branch library.

A Finzer School Community was built and set up upon the school room floor. For the first time, the constructional was large enough to allow the children to work and play in the buildings. Natural flowers, grown from seeds that they had themselves planted, bloomed in the florist shop. They actually sold groceries over the counter in the grocery store. This entailed the use of money and the counting and weighing of commodities. Arithmetic in such a situation was not a thing apart but a real experience. Change had to be made; eggs, oranges and bananas had to be counted; sugar, rice and hominy had to be weighed. Then too, these chlldren learned the dates of the month for keeping the library records; they bought stamps from their drug store (entalling the use of addition, subtraction, and multiplication) and made charts to keep records of dates of planting, germination, and various stages of growth of the seeds they had planted. 
Lack of floor space proved our greatest handicap and It become necessary to replace one building with another instead of having an aggregate ensemble as we had at first planned. These difficulties seemed to kindle rather than dampen the enthusiasm, however, and even the janitor made room in an already overcrowded basement for cartons that were to be used at a later date but which had to be secured whenever and wherever possible.

We now had a teacher in the kindergarten, in the first grade and in the second grade who were basing their teaching upon life experiences and creative activities. With supervisor, principal and teachers in accord on this basic philosophy, results were beginning to show.

The following year (1930) brought Miss Elsie Clapp, who had formerly worked with Dewey, to the Ballard School, near Louisville. Miss Clapp gave courses in the principles of progressive education at the University of Louisville, and two more of the Finzer primary teachers, Miss Elsie Vaughan and Miss Cordelia Sims, enrolled in one of her first classes. Since Miss Clapp always made provision for her classes to visit the Ballard School, these teachers had the advantage of seeing the principles of progressive education carried out under more or less ideal conditions. It was Miss clapp's policy to point out the feasibility of incorporating progressive practices into traditional classrooms. Teachers in her classes were encouraged to work out unit plans which were applicable to their own situations. 
As may be seen, the roster of teachers having experience with the philosophy and principles of the new education was steadily increasing. Undoubtediy the influence of their practices carried over to the other teachers who had been less flexible in their thinking. Evidences of increased activity were seen in the greater amount and greater variety of expressional work executed, such as making booklets, pictorial borders, making animals, making toys, etc. This, however, was not fundamentally significant because expressional work in itself is not indicative of real experiencing. It is possible to have constructional work that is just as isolated as compartmentalized subject matter. However, any experimentation along the lines of the newer practices seemed significant in certain classrooms.

As may be seen, the increase in the activity type program was taking place in the primary grades. Five of the primary teachers had now been enrolied in classes dealing with the princlples of progressive education. They had worked out units and tested them in their classrooms. They had observed the practices in a progressive school and were carrying out their work on the basis of Iife experiences and felt needs of the children. They were alded and encouraged in their work by the generally changed attitude toward the curriculum in the elementary school. Especially in the primary grades was this true. The unit type program was replacing the separate-subject type program, and the 
time schedule began disappearing from teachers' doors. Instead of the ten, fifteen and twenty minute periods of unrelated teaching, a long period constituted the activity period. The principle of educating the whole child recognized that initiating, planning, purposing, and creating called into play so many interrelated learnings that no sharp line could be drawn for language, composition, history or geography. When the need arose, it was met, regardless of subject name or time schedule. Primary teachers especially were beginning to think in terms of the unit curricùlum. They saw how the child's interest motivated the work and how this interest was carrying over into related subjects when a definite purpose was seen.

In the upper grades, the junior high school organization was affecting the few elementary schools which still retained the seventh and eighth grades. History and geography were no longer taught separately, but were merged into "social studies". The school day was lengthened, and 50 or 55 minute periods replaced the 30 or 45 minute periods. More attention was given to physical education and in a different way. Games, including football, baseball, basketball and volley ball, became part of the school program. Vocational education was emphasized by longer periods in the shops and kitchen. Future planning with the children as to choice of a life work, and guidance in securing necessary information and if possible, experience, became 
an important part of the work. Clubs gave opportunity to include certain desirable phases of art, literature, dramatics, athletics, and vocations that the regular course forbade. The Finzer School welcomed the opportunity to embrace what it could of the newer plan. Physical handicaps limited its possibilities, however. Here again, modification and adaptation were the best that could be accomplished.

- The social studies plan, instead of the old separated history and geography periods was a welcome and easily acquired innovation. The new Rugg Social Science Books, with their companion work books, replaced the separate history and geography texts. Problem solving became the plan of procedure. For instance: Why is immigration into cities conducive to poverty? or Why do trade and transportation tend to follow natural highways? or what land shall be reforested?

In solving the problem at hand, every resource possible was exhausted. Books, newspapers, magazines, the public library, the Filson $C l u b$ and the Department of Education in Washington were consulted as the needs arose. In attacking the problem, it was customary to divide the class into groups so that different aspects could be investigated. Each group elected a chairman, who was responsible for the final summation of the results of that particular phase of the larger question. 
This sumarization took different forms. Sometimes the chairman made an oral report of the work done by his committee. Sometimes the work was in the form of an exhibit which had been assembled for the class. If this were the case, an explanation of the collection was the method of reporting results. Sometimes a group elected to work out a dramatization to clarify a problem. In this case, the final performance became the report. Again, - a group was given the opportunity of planning and securing suitable pictures for the class bulletin board. One instance of particular originality was displayed by a group that made lantern slides put of old window glass and then borrowed the lantern from the central office so that the slides could be used for demonstration purposes.

It may be seen how creative thinking entered, both in the problem and in the method of attack. The teacher's place had been changed entirely in this new scheme. She became adviser and guide instead of instructor. She made suggestions but the children made decisions. It was her purpose to present vital problems which would challenge the best possible efforts and at the same time develop desirable social attitudes in the children. Her position was most strategic in this respect. Present day problems such as the national income and its distribution or technological progress and its effect upon production gave excellent opportunity to guide the thinking of her group along the line 
of future planning. Children were given the ldee that problems change with conditions, that experience must constantly be reconstructed in the light of present circumstances, and that we have no certain knowledge of the future. This was the phllosophy behind the plan and method used with the older children.

It was this type of thinking that we were endeavoring to secure and it is this type of problem solving that we have made, and are continuing to make, the basis for our social studies procedure in the Finzer School.

In science, as in the social studies, significant changes in content and method have been seen. The laboratory method has superseded the textbook method and the subject is attacked through the problem to be solved. Since there is no laboratory in the Finzer School, our experimentation is limited by our equipment. However, a problem such as "How Man Lights His Home" gives much opportunity for experimentation.

English has always been rich in opportunities for creative thinking, purposeful activity and development of appreciations. We have long used the unit type of organization in this subject because it has lent itself so easily to this form. Excursions have provided opportunities for a great diversity of expression. The trip had to be planned. Permission for it had to be requested by a letter. Transportation had to be provided. What was to be looked for required 
a carefully planned preparatory outline. How the acquired information was to be used required decision. A letter of thanks was necessary upon their return. The ramifications were great.

In working out a problem in the classroom, the same procedure as that followed in the social studies department was seen. Small groups worked on phases of the big problem. Pictures, exhibits, bulletin boards, original poems, plays or stories, dramatizations and programs expressed the creative work.

The intermediate grades were also feeling the effects of the unit type of organization. It had always seemed as if the experiencing that was provided for the children of this age level was less vital than that of either the older or jounger groups. The spontaneous activity of the Iittle children and the adolescent interests of the older ones seemed to overshadow this intermediate group to an unwarranted degree.

For this reason we felt an especial sense of gratification when the fifth grade asked to have a school garden. It was in the early days of the depression when the plea to "plant a garden" was heard on all sides. During a meeting of the Current Events Club, this plea was discussed. The question was raised by one of the children as to whether it wouldn't help if the class had a garden. The question was taken under advisement because no one could suggest 
where the garden might be planted. It. was later decided to refer the question to the principal with reasons for the request.

This seemed a rare opportunity to secure the type of experience that had long been desired for these children. However, the old-fashioned brick school yard hemmed in by sheds, fences and garages made any planting on the school premises an absolute impossibility. The children were told that we would appeal to the entire group of teachers at the next faculty meeting for help in solving their problem. This brought a new idea into their minds.

- Maybe other classes would l1ke to have a garden too, and they could work together. Further discussion suggested still another possibility. Why not have a big garden, at least big enough for the whole school to use and then call it the Nicholas Finzer School Garden.

When the question was brought up at the faculty meeting, opinion as to the advisability of the project was divided. Location was the first stumbling block, lack of implements another, and a cold, rainy spring still another. Miss Smith suggested, at once, a vacant lot two doors from the school. This lot had long been used as a neighborhood dump and seemed to be in a hopeless state as far as a garden was concerned. Miss Gwaltney agreed with Miss Smith that the lot had possibilities and offered to be a member of a committee to investigate its use for the school. 
Miss Smith, Miss Gwaltney and two of the fifth grade children composed the committee. Since no one knew who owned the lot, this was the first problem to be solved. A neighbor was discovered by one of the children who knew the owner and gave us his address. The committee visited the owner without delay. He not only gave his unqualified permission for our use of the lot, but urged us to call upon him if we needed additional help in clearing away the rubbish.

The fifth grade wrote a letter of thanks to the owner, and then began on a plan for the organization of the school. It was decided to send a speaker into every room of the school to explain the purpose in having a garden and invite each class to participate. In preparation for the announcements in the rooms, the children agreed that they must know about the garden before they spoke, so that they would be able to answer any question which might arise. They listed on the board all the reasons for having a garden, what they hoped to do and how they planned to do 1t. From this they developed an outline which they used to help them in making talks for the various grades. Each child in the room prepared a talk for a certain grade-division in the school. They were allowed to choose the grade which they wanted, because it was pointed out that the speakers for the lower divisions would have to be very careful that the little chlldren understood what they were trying to tell. After 
a check had been made to insure a speaker for every division, they went to work upon their speeches. Since there were thirty-eight children and only elghteen rooms, the speakers were selected by popular vote in the class. A set of standards for judging the relative value of the talks was decided upon and placed on the board. With these in mind, the class passed upon the merits of each speaker and made Its choice:

The speakers were enthusiastically received and the interest ran high. Since the fifth grade had conceived the Idea and inftiated the activity, it was decided to hold them in the position of a steering or executive comittee. They imnediately asked that each grade-division appoint a class representative to meet with them.

Plans for effective administration were discussed in each room. Excellent suggestions came from the different groups and were referred to the large committee. In securing these suggestions, the teachers presented the problem from all angles. Not every class thought of the same aspects, but the more significant difficulties were suggested by all. For instance, "How shall we water the garden?" was discussed from the first grade through the eighth, but the question, "What is the composition of the soll?" showed the more mature thinking of the older children.

The final list of problem solutions which had been evolved by the entire school presented a significant array of 
analytical data. A few of the solutions are listed to show the nature of the problems raised.

1. Give an Easter sale to raise money for the garden implements.

2. Visit the office of the Supervisor of School Gardens (Miss Yunker) for suggestions.

3. Visit the garden of a nursery-man on the 18th Street Road. (The owner was a relative of a first grade child.)

4. Interview a neighbor to secure permission to use hydrant. 5. Write to the Department of Agriculture in Washington for brlletins.

6. Interview the neighborhood florist for suggestions as to the use of fertilizer.

All of the above listed suggestions were used. The Easter sale proved to be a unit within a unit. The entire school participated with a common interest. The suggestion came from the $6 \mathrm{~b}$ class, so they were allowed the major responsibility, but every class cooperated. Eggs. were dyed and decorated, and soft toys in the shapes of rabits and chickens were made of flannel and stuffed with cotton. Easter cards were designed and block printed. Posters advertising the sale were placed in the halls and in neighborhood stores. Invitations were written to parents and friends. Not only was the original purpose of raising money fulfilled, but valuable educational outcomes were achieved. The common purpose and large group participation engendered a closer relationship throughout the school. 
Arithmetic was seen in a new light by the children as a result of the sale. The need for funds was definite. The purpose of the sale was clear. It was necessary to buy materials for articles which were later to be sold. Comparative buying, profit and loss entered here. Percent of cost price which must be charged as gain, number of articles which must be sold to reach a certain monetary goal, a system of marking to insure perfect understanding among the salespeople - these were but a few of the problems which arose. A record had to be kept of expenditures and accounts balanced. Money had to be counted and a bank account opened. The whole plan was rich in opportunities to incorporate arithmetic into life situations. Unusual interest was shown by the children in solving problerns which were necessary to the successful carrying out of their enterprise.

From the funds earned in this sale, garden implements, seeds, whitewash brushes and materials were purchased. Fertilizer was sent as a gift from Miss Yunker, who was enthusiastic over the plans which the children presented when they visited her. She gave them valuable suggestions as to the actual planting procedure.

The visit to the 18th street Road nursery required much planning from the standpoint of transportation arrangement. This has always been a major problem in our school from the financial angle. Carfare, especially interurban fare, 
excludes so many children that its consideration is rejected. Automobiles are not plentiful enough in the school to be the answer. Trucks offer the best solution if the trip can be arranged at a time when their use in business is not demanded. The committee finally completed arrangements whereby transportation for a group of five from each room was arranged. Other children were welcome if they could go in their own automobiles or on the car.

The children learned much from this visit about the care of the growing plants. One of the questions that they were asked to find out was how the garden should be laid out. They brought back clearly defined ideas about which plants should be placed against the fence, which in the center spaces and why. Many other leads, initiated by this trip, were followed upon their return to school. For instance, what insects must be guarded against; what preventive measures the nursery man takes to avoid plant blights; what hybrids are; what causes the difference between the cultivated flower and the common garden varlety. It may be seen how many related avenues were opened and what enrichment occurred in the background of both children and teachers by this experience.

The neighbor who was interviewed about the hydrant became one of our most valuable friends.. She said that she was so glad to see the dump cleared that she 
would do anything to help. She suggested the use of her garden hose, which we had not asked for, but which was gladly accepted.

The material that was received from the Department of Agriculture in response to a request from the seventh grade class became the nucleus of a reference library on the garden and related subjects. It was decided by the children that since all grades would require access to source material, it would have to be in a place where it could be consuited at any time without disturbing other classes. They suggested a library table in the second floor hall. This was agreed upon and a reference library started. Children, teachers, parents and friends gave or loaned books. Seed catalogues, planting guides and charts were secured from seed houses. Nature magazines were assembled, and any pertinent articles from newspapers were mounted in a scrap book which was placed on the table for this purpose. A most satisfactory library was secured in this way.

The mathematics department had an important place in this project. The departmental children did all the measuring and lining for the division of ground among the classes. They drew a plan of the lot and made a working drawing of the complete lay-out. A third grade class had suggested making a bird bath, so this was included in the working drawing. It was submitted in completed form to 
the executive committee for conslderation. This group questioned the location of several plots, but the reasons advanced for each point questioned seemed to satisfy the committee and the drawing was accepted.

A schedule was arranged, with the help of the teachers, for actual working in the garden. Every class had had a share in clearing the ground. The seventh and eighth grade boys were now ready to lay out the space according to the working drawing. They began without delay and at the same time the fourth grade was busy whitewashing the fence. Each class was responsible for working the ground, fertilizing it, selecting the seeds, and planting them in its own plot. The older children helped the little children in the preparation of the ground. The little ones wanted to do everything themselves, so they compromised by breaking up clods with a trowel.

When the schedule became operative, the work moved easily and without seeming effort. If a class needed the garden period for work in the room, they didn't go over to the 1ot. If more time was needed on a certain day than the schedule allowed, another group might be willing to waive or exchange periods. The time allotment was merely for the purpose of guaranteeing opportunity for all, and the classes were free to make any modifications that met with the approval of the others concerned.

While the original purpose was to make a vegetable garden, 
certain classes wanted flowers, and so these were included. Records were kept of the dates of planting and results were anxiously awaited. The ground was watered daily and the process of germination was the peak of interest in the school.

Several parents sent hardy plants from their yards for the garden and these were planted around the bird bath which the third. grade class had made of stones piled into a mound in which an old dish pan was lodged.

When the plants began to grow, activity was renewed. The ground had to be kept loose around the roots, seedlings had to be transplanted and weeds pulled out. The children were not only interested in their own plots but also in those of the other grades. When the second grade's lettuce was ready to be picked, excitement ran high. The first grade's radishes were not quite ripe and so honors for first fruits went to the second grade. A salad was made of the lettuce in the room by way of celebration, and the first grade was invited to the feast.

Provision for the garden's care during the summer was the next concern. The problem of watering, weeding the ground and picking the flowers and vegetables had to be solved. It was decided to ask for volunteers in each room for the summer work. Next, these volunteers had to bring signed notes signifying their parents' willingness to have the children spend part of the morning in the garden. The flowers and vegetables ready for gathering 
each morning, were to be divided among the workers. Splendid response was received. Children were anxious to come and parents were glad to have them gainfully occupied.

This garden project was the high spot in experiencing - that had been achieved up to that time. From the standpoint of subject matter integration, it ranked high. Even the little first grade chlldren kept records of dates of planting seeds, of seeing first sprouts, and of watering and weeding. Miss Smith used their records as the basis for reading, spelling and conversation lessons. In every grade from the first to the eighth, oral and written expression, arithmetic, science, health and art were vitalized and integrated.

From the standpoint of group participation, cooperation and sharing, it left nothing to be desired. As a life experience, it fitted the needs of every child.

In regard to learning situations and problem solving, It was almost perfect. There were so many problems, and they were so constantly presenting themselves, that no one was ever quite through. Man's struggle with his environment was definitely sensed by the older groups.

Creative expression as well as creative thinking was seen in the making of bird sticks, bird houses, bird bath and garden bench.

Adaptation to situations was constantly exemplified in 
the many compromises that the children were called upon to make. They developed a fine spirit that seemed to have carry-over effect in the school generally.

The garden project seemed to mark a turning point in the general procedure in the school. An acceptance rather than a toleration of life experiencing seemed a result of these activities. A better understanding of the philosophy underlying the newer trends in education was evident. The unit type of teaching was seen in all grades with less and less of the old formality.

More and more of our teachers were enrolling in classes of progressive education. In 1931 and 1932, and again in 1934 and 1935, Miss Louisa Lawton conducted these classes at the University of Louisville. She emphasized the shift from subject matter to child; the need for developing the ability to live, work, and play with others; the importance of providing worth while experiences, and the idea of growth through purposeful activity. Among the teachers coming under the influence of this thinking were: Misses Mabel Smith, Lottle Gwaltney, Florence Lowd, Elsie Haemish, Elsie Vaughan, Lorena Bryant, Hazel Grimes, Marvin Tyler, and Maxine Deddens.

Each of these teachers prepared a unit with these princlples in mind, and later used it in the classroom. Among the subjects chosen by these teachers were the following: The Pet Shop, Community Helpers, Indian Life, 
Mediterranean Countries, The Feudal Age, and The History of Printing. Since these units were worked out in the fullest detail with attention to every possible creative activity, it may readily be seen how their use influenced the school and the teacher's viewpoint.

In addition to this original work of the teachers, an excellent collection of units has been made available for use as a result of the work of a curriculium committee under the direction of Miss Mary Browning, Primary Supervisor of the Iouisville Public Schools.

As has been repeatedly pointed out, we are always hampered by the physical Iimitations of the school plant. We have long wanted some type of a workroom where children could go, alone or with a group, to do such creative work as was impossible in the crowded classroom. In the workroom, for instance, materials would be readily available, in the classroom, this was not possible. Since the size of the rooms and the number of children in each, make the inclusion of a work table out of the question, there is no legitimate place to keep paste, scissors, calcimo, paper, clay and the like, except in the cabinet in the cloak-room. Then too, any work on a large scale requires more space than the rooms afford if all or a large number are working.

This jear, through a rearrangement of classes, it has been possible to use two rooms, one on the first floor and one on the second floor, for work-rooms. Desks were removed 
and several primary tables and small chairs were put in their place. The children and teachers had great fun in equipping the rooms. Since we had no money to spend, equipment became a matter of initiative and ingenuity. We kept the teacher's cabinet in the room and collected orange crates which we used as low cupboards around the walls. The crates were painted dark green with calcimo paint and they presented a neat appearance when completed. The teachers pooled their supplies of colored paper, calcimo, clay, yarn and cardboard to get a working basis of materials. Tools appeared as if by magic. Children from every grade loaned hammers, saws, planes, chisels, and pliers. These were carefully labeled with the name and grade of the owner and arranged in the cabinet in each work-room. The large jar of clay, formerly kept in the basement, was moved to the first floor work-room. Two easels (already in the school) were placed in each room for calcimo painting. Several fathers donated lumber for our use - one of these works in a planing mill and he saves all scrap wood for our boys. The first grade children, with an occasional Iift from the fourth grade, made nail boxes out of some of this scrap wood. The fifth grade boys helped the third grade make a set of shelves for a rock collection that they were assembling in their room. Examples of cooperation, of sharing, of leadership, of initiative, and of creative 
thinking were seen throughout this period of equipping the work-rooms. The ldea of using orange crates for cupboards came from the children, as did also their suggestion of bringing tools from home. The labeling and arranging of the tools was a solution to the problem, "How shall we keep the tools from becoming mixed up?" In fact, the inftlating, planning, solving and executing of each step in the rooms' equipment was primarily effected by Miss Gwaltney's third grade class for the first floor room, and Miss Lowd's second grade class for the second floor. Both of these groups called in older boys for help when the need arose. When the rooms were once equipped, they became available for use by any grade.

Teachers are finding more and more uses for these rooms. They serve splendidy for the purpose of allowing a group to work out a dramatization independently. They also make possible a surprise program for another part of the class. Best of all they provide sanctuary for precious bits of constructional work that must be left and should not be disturbed. When the third grade class was making pottery, articles in various stages of modeling, painting and decorating could be left without moving or touching them until such a time as it was safe to put them away. The plan offers greatly increased opportunities for freedom and initlative. It encourages fuller expression of the fundamentally valuable impulses of manipulation, 
investigation and communication.

Significant evidences of the inquiring attitude of mind and the attempt to solve their own problems are seen all over the school. For instance, three of the elghth grade boys brought to school a theatre that they had made at home to remedy the defects of the school theatre. Without any suggestions from their teachers, they went to work on this problem. They had been dissatisfied with the size of the school theatre because it necessitated the use of small marionettes. It also lacked sufficient helght for manipulation of the marionettes without stooping. Another fault lay in the fact that the footlights reflected light into the eyes of the audience. These were remediable defects to Billy Hood, Edgar Whitehouse, and J. 0. Bagwell, and so they went to work. They discussed the procedure very naively: "We wanted to make a new theatre because the school needed one. We wanted a larger stage so that we could use bigger marionettes and have more room to work them in. We made it in Edgar's garage. We used half of an old table top for the stage. Billy's Daddy gave us the wood and his uncle, who works at the Vendome Copper and Brass Works, gave us the copper for our reflector. The nails came out of old lumber. The bevelled edge on the front of the stage came off of the table top that we used for the bottom of the stage. J. O. gave us the 
sandpaper and the paint. We used Billy's tools: a trisquare, rip saw, cross cut saw, miter saw, chisel, plane, brace and bit, wood clamp, pliers, hammer, keyhole saw, drawing knife and bolt cutter. We had lots of fun making the theatre and we're so glad it's made because we just had to have it to use in our work."

Probably no greater compliment could be paid to the activity program than that "we just had to have it to use in our work." If we can 80 stimulate the children to overcome difficulties, to meet and conquer the situations as they arise, to discover and correct defects, and to display such initiative, surely we are putting invincible tools into their hands.

It has been the purpose in this chapter to show the evolution of the activity program in the Nicholas Finzer School. To further clarify this picture of gradual growth, two outlines follow.

EVOLUTION OF ACTIVITY PROGRAM IN THE

NICHOLAS FINZER SCHOOL

1923 Unit plan in 8 a (continues to 1930) Balance of school formal (continues to 1926)

1924 Same as in 1923

1925 Health Pageant in entire school - correlation of subject matter in all subjects

1926 Iittle Theatre Project - constructed by intermediate and upper grades and used by entire school 
1927 Unit plan continuing in $8 a$

Unit plan initiated in kindergarten

Unit plan initiated in first grade

1928 Unit plan continuing in $8 \mathrm{a}$

Unit plan continuing in kindergarten

Unit plan continuing in first grade

Unit plan initiated in second grade

1929 Same as in 1928

1930 Unit plan continuing in $8 a$

Unit plan continuing in kindergarten

Unit plan continuing in first grade

Unit plan continuing in second grade

Unit plan inftiated in third grade

Unit plan initiated in fourth grade

1931 Garden project in entire school

Unit plan same as in 1930

1932 Problem solving with emphasis upon changing 8 th grade social conditions and present day problems 7 th grade

to Arithmetic and spelling taught separately

1935

Unit plan with major center of interest. Integration effective to a large degree, but skills taught as formal subjects

6 th grade

5 th grade

4 th grade

Most successful demonstration of unit

plan with greatest degree of integration

3ra grade

2nd grade

lst grade kindergarten

In the following table, Types of Units Used, the names of some units experienced during the evolution of the program will be listed. No effort is made here to list all of the units used in each grade during the whole program. Only those are recorded which show the initiation of the various grade-divisions into the program. 
TYPES OF UNIIS USED

\begin{tabular}{ll} 
Year & \multicolumn{1}{c}{ Title } \\
1923 & America's Problem - \\
& Imigration \\
A Barrier Made a \\
Highwy \\
1925 Safeguarding Our Nation
\end{tabular}

1925 The Gift of Health A Pageant

1926 Little Theatre Project

192. Home Unit The Toy Shop

1928 Our Community

1929 An Indian Unit

1930 Pioneer Unit Playgrounds Unit

1931 Garden Project
Grade

8 th

entire school

entire school

kgtn

ist

2nd

$3 r d$

4 th

2nd

entire Most successful large school group participation to date. Real experiencing.

Ist 2nd 3 rd

4 th

5 th

\section{Remarks}

Units did not meet needs of children. While they did show correlation, the emphasis was upon subject matter.

Second and more successful attempt at large group participation.

Beginnings of a full unit type of program.

Shift from rigidity of curriculum to more informal procedure.

Continued shift to more informal procedure.

Greater integration, but subject matter lines still drawn.

Unit is the curriculum.

Unit integrates work but skills are tought separately. 


$\begin{array}{llll}1932 & \text { Contribution of Greece and } & 6 \text { th } & \begin{array}{l}\text { Problem solving, } \\ \text { to }\end{array} \\ 1935 & \begin{array}{l}\text { Rome } \\ \text { Development of Machinery } \\ \text { in the Uniteä States } \\ \text { World Markets }\end{array} & 7 \text { th } & \begin{array}{l}\text { matter, but skills } \\ \text { taught separately. }\end{array} \\ & \text { 8th } & \end{array}$

In looking back over the period of years that have just been touched upon, there is a feeling of encouragement rather than discouragement. There have been weaknesses and difficulties throughout, but they have become stepping stones to greater accomplishments.

Certain phases of the philosophy of the new education have been largely accepted by the faculty. There is increasing evidence of its permeation throughout the school. Teachers see the increased interest of the children; that there is less fatigue; and that disciplinary problems cease when children are actively and purposefully engaged in a worthwhile endeavor.

Plans for the future will be fully discussed in the final chapter of this study, so here it need only be stated that it is our intention to go on with this type of work. Attitudes of experimenting, testing results, accepting, rejecting, planning, and creating are the desired goals for all concerned. It has been demonstrated that the basic principles of the activity program are applicable to any classroom; that children grow in intelligent self-direction through its experiencing; and that teachers who whole heartedly embrace 1ts precepts are happy in their work. 
CHAPTER IV

CRITERIA FOR EVALUATING

THE

ACTIVITY MOVEMENT 
CRITERIA FOR EVALUATING THE ACTIVITY MOVEMENT

It is the purpose of this chapter to state briefly, those criteria which have been set up by outstanding educators for the evaluation of the activity movement. With these in mind, a set of criteria will be recorded which have been evolved for the measurement of the activity program in the Nicholas Finzer School. An effort will be made to justify their selection.

Brim, in discussing criteria for the new education, believes that, with few exceptions, neither proponents nor critics of the movement have delved deeply enough in establishing their criteria. ${ }^{I}$ He looks to the fields of philosophy, psychology, blology and sclence as fundamental bases of measurement. He believes that criteria in general "are practical and empirical rather than fundamental", and that "as such they give little vision or little security."2

While he does not actually offer criteria for consideration, he points to certain fields for vital implications. For instance, "Science, gave us an attitude and method adequate to the new challenge. We must educate for intelligent self-direction." 3 and, "On the psychological side

1. Brim, Orville. Op. cit., p. 333.

2. Ibid., p. 333.

3. Ibid., p. 332 . 
the activity school conceives the child as a dynamic, purposing organism rather than as an atomistic, responding mechanism."I Again, "The field of biology gives abundant evidence that emergent evolution is in this area a fact."2 These and other statements indicate Brim's conception of the areas from which he says tenable criteria must come. It is interesting to note the criteria set up for the evaluation of the educative process as found in Appendix 8, of the Yearbook on the activity movement. Such outstanding educators as Jean Betzner, Edna Brandenberg, John Childs, Genevieve Coy, Grace Downin, Roma Gans, Ellen Green, Paul Hanna, Bernice Newell, Thomas L. Hopkins, Ella Marie Itse, Alice Keliher, Mildred Mead, Marie Merrill, Grace Mink, Lois Coffey Mossman, Florence Nichols and Ann Richardson participated in the preparation of these criteria. They are listed under general headings and clarified by a group of questions under each main heading. The major criteria follow:

"1. Are there experiences under way that promote growth in habits of critical inquiry?

2. Do the activities under way offer opportunity for experience in many kinds of meaningful endeavor through physical and social needs?

1. Ibid., p. 332.

2. Ibid., p. 333 . 
3. Are the activities under way such that the individual may discover his interests or tendencies?

4. Do the experiences under way impel the members of the group on to increasingly challenging endeavor?

5. Are there experiences under way that promote sharing of experience through social participation?

6. Will the learnersacquire increasing freedom to order their own experiences through effective assumption of responsibilities?

These criteria seem to cover successfully those ends which we could wish education to accomplish for our children. As such, they seem to provide a satisfactory measuring rod to apply to individual schools under various conditions. If, as we so strongly believe, it is possible to incorporate the principles of progressive education into any situation and thereby modify teaching for the ultimate good of the group, the criteria referred to are distinctly illuminating.

In the Nicholas Finzer School we have evolved a set of criteria which serve as an evaluative guide without in the least conflicting with the required conformity of one school in a large system. The criteria follow:

1. Does the activity selected meet the life needs of the children?

In considering this criterion, an analysis will be 
made of the physical and social needs of the group. If the activity is closely related to the child's Iife, interest should be high because it will be within his experience.

2. Does the activity provide for "creative learning"? In setting up this criterion, it was with the idea of emphasizing scientific findings on this point. The principle of learning through discovery, and growth through spontaneous activity were considered.

3. Does the activity provide for all-round development? In thinking of development, the child's physical growth, mental growth, manipulative growth and growth in appreciations all are considered.

4. Does the activity provide opportunity for intelligent and efficient participation?

The thought behind the inclusion of this criterion is that the participation may be effected with the child as a leader, as a follower or as a cooperator. In any role the ldea of participation is the important one.

5. Does the activity provide for social development? The idea of cooperation, sharing, working together in a group, contacting people in the community, and developing attitudes of toleration and understanding are considered in this criterion. 
6. Does the activity provide situations in which the children may learn to evaluate, question, accept or reject as the case may demand?

In the light of our dynamic, changing world, it is important that children learn to weigh problems and make decisions as the need arises.

7. Does the activity have leading-on qualities?

In explanation of this criterion, it may be said that by "leading-on" qualities is meant possibilities for development, and experiences that are an outgrowth of the unit being studied.

In checking pupil growth resulting from the experiencing of activities, various tests and devices are employed. These include:

1. Standardized achievement tests.

2. Tests made by the teacher.

3. Observation by principal and teachers.

4. Records of children's work.

With the exception of the achievement tests and certain objective tests made by the teachers, this evaluation is largely subjective.

A significant advance over this type of measurement is shown in newer practices in the evaluation of progressive education. Pistor ${ }^{l}$ gives a detailed account of a scientific

1. Pistor, Frederick. "A Valid Scientific Appraisal of an Enterprise in Progressive Education", Journal of Educational Research. pp. 433-449. February, 1935. 
appraisal of the growth of fifth and sixth grade children under experimental conditions. His study reports a four year investigation of the outcomes of progressive education measured scientifically.

Wrightstone ${ }^{l}$ reports a similar but less comprehensive study of the evaluation of an integrated program. Both investigators appraise the intellectual factors of the children in an experimental and control situation by the equated groups technique.

The results of such appraisals are highly significant and point the way to a more scientific evaluation for all schools.

1. Wrightstone, J. Wayne. "An Evaluation of the Integrated Curriculum in the Upper Grades", The Elementary School Journal. pp. 583-587. Apri1, 1935 . 
CHAPTER V

EVALUATION OF THE SCHOOL

IN THE

LIGHT OF ACCEPTABLE CRITERIA 


\section{CHAPTER V}

\section{EVALUATION OF THE SCHOOL \\ IN THE LIGHT OF ACCEPTABLE CRITERIA}

In Chapter IV, criteria for evaluating the activity movement were discussed. Those worked out by a special committee of nationally prominent educators were stated and those evolved for use in the Nicholas Finzer School were explained.

It is the purpose of this chapter to consider the Finzer School in the light of these criteria.. They are repeated for convenience of reference:

Criteria of National Committee

"I. Are there experiences under way that promote growth in habits of critical inquiry?

2. Do activities under way offer opportunity for experience in many kinds of meaningful endeavor through physical and social needs?

3. Are the activities under way such that the individual may discover his interests and tendencies?

4. Do the experiences under way impel the members of the group on into increasingly challenging endeavor?

5. Are there experiences under way that promote sharing of experience through social participation? 
6. Will the learners acquire increasing freedom to order their own experfences through effective assumption of responsibilities?"

Criteria for Measuring the Nicholas Finzer School

1. Does the activity selected meet the life needs of the children?

2. Does the activity provide for "creative learning"?

3. Does the activity provide for all-round development?

4. Does the activity provide for intelligent and efficient participation?

5. Does the activity provide for social development?

6. Does the activity provide situations in which the children may learn to evaluate, question, accept or reject as the case may demand?

7. Does the activity have leading-on qualities?

It should be recalled that the earliest efforts along the line of the activity type of work in the Nicholas Finzer School were orlginated in the departmental grades. From the standpoint of the criteria which have been set up, these early attempts are definitely found wanting. Since only one unit, Color, was described in Chapter III, it will be helpful in understanding the deductions made in evaluating the school, if a few titles of units studied are given. Some of these which were experienced during 
the years, 1923-1928, follow:

1. Book Friends

2. Kentucky Mountain Life

3. A Study of our Parks

4. Safeguarding our Nation

5. The Finzer Folder: Our School Paper

6. Bird Friends

7. The Diphtheria Epidemic at Nome, Alaska

8. A Barrier Made a Highway - World Friendship

9. Our World of Beauty: Art, Music and Literature

10. America's Problem - Immigration

It may be seen at a glance, that in the main, the selection of these activities did not meet the life needs of the children nor help them discover their interests and tendencies. For instance, the unit, A Barrier Made a Highway, presented nothing that could be construed as a life need for these children, nor did it fulfill to any degree the other attainments set up as desirable. It provided only slightly for growth in habits of critical inquiry and meaningful endeavor through physical and social needs. There was little in it that provided for effective assumption of responsibilities and leading-on qualities were non-existent.

This same general criticism applies in greater or less degree to the other units. As a whole, the units do not represent the life needs of the children. They do not 
take into consideration sufficiently, their interests and tendencies. Some provide more than others for social participation through sharing of experience, but considered generally, they do not measure up to the criteria set for the school.

One of these experiences, however, the school paper, was a significant exception to the general criticism. This particular class initiated the school paper during the last half of its eighth grade year, and it represented the most vital experience in their school life. A trip was taken to the Courier-Journal and Louisville Times Building and the entire plant visited, including business offices, editorial rooms, circulation department, reporters' rooms, library, telegraph offices, cartoonist's office and press rooms. Upon their return to school, all those problems which needed consideration were listed and attacked. These included the following:

1. How could the interest of the entire school be aroused so that all would want to participate in the project?

2. How could the staff be elected so that the 8 a could assume management and yet include representation from the entire school?

3. How could the paper be financed?

4. What shall be the name of the paper?

5. How shall this name be chosen so that the whole school may have a part in its selection? 
6. How shall the paper be advertised so that parents and friends may know about it?

7. How shall the material be collected and assembled for the press?

It may be seen how this activity fully met the test demanded by both sets of criteria recorded. Creative thinking, meaningful endeavor, life needs and interests, social participation, assumption of responsibilities - all these were achieved in full measure.

The evaluation of the other departments of the school at this time is more difficult. Since the incorporation of activity practices into the school was a gradual one, and since this departure from traditional procedure occurred in the upper grades, the primary and intermediate departments still presented a formal picture.

Although the regular course of study at that time used the term "large units of thought", activity was almost entirely in the nature of conversation about experience rather than actual experiencing itself. Constructional work fulfilled course of study requirements and little was done in the way of creative expression. For this reason, the criteria set up to measure activities, cannot be used to measure the plimary and intermediate work of this particular period.

Very shortly after this, however, unit teaching of a 
truly progressive type made its appearance in the school. In 1927, to be exact, the kind of experiencing for which our criteria were evolved, was evident in two grades in the school. From 192' to 1930, the gain was gradual but consistent. Some of the units which were experienced during those years are as follows:

1. A Series of Trips to Become Acquainted with Our Community

2. The Christmas Gift Shop

3. Farm Life

4. A study of Birds

5. Primitive Life in the Cave Period

6. The Pioneers

7. Children of the Mediterranean Countries

8. Early Exploration in America

These units were much more inclusive than their titles suggest. All of them were within the range of the children's experience and connected with their needs. They provided for social development and creative thinking. They were sufficlently challenging to encourage the children to go on in their endeavors.

From the year 1930 to the present time, the criteria have served as a measure of the entire school. It must not be inferred that all activities experienced have in any sense fully met the set standard. It may be said, 
however, that the type of experiencing has so changed that the criteria are applicable to procedure in each grade. This seems highly significant in the light of past experience. Since so much of the work in the upper grades is presented in the form of problems to be solved, some of these will be listed:

1. How have exchange and commercialism affected man's occupancy of the land?.

2. How has the study of bacterial causes, and the practice of preventive medicine lengthened human life?

3. How can poverty in a land of plenty be explained?

4. How has the application of scientific knowledge helped $\operatorname{man}$ ?

5. How can the problem of excess leisure be met?

6. How may the study of the arts reveal the culture of a people?

7. How will a knowledge of the world and its natural laws serve as a protection against superstition?

8. What relation has progress to the discovery and observation of natural laws?

The solving of these problems brings into play all the experiences and activities that we are attempting to measure. Creative thinking must be applied to the problem under consideration. Group participation, purposeful endeavor, assumption of responsibility, critical analysis, 
and leading-on qualities are definitely present in this type of learning.

The children of the intermediate grades are now experiencing as richly as those of any other age level. For a long time there seemed to be a tendency to emphasize the activities of the younger and older children with a consequent overshadowing of this particular group. Activity seemed to center largely along the line of book clubs, committee reports and current events discussions. While these are all valuable adjuncts of a larger program, they are not ends in themselves. For some time, however, there has been a definite effort to remedy this defect. Particular attention has been directed to the working out of units to fit the physical and social noeds of this group. As a result some excellent units have been achieved. The following list embraces some of those which represent the experiencing in the intermediate grades of the Finzer School during the last few years:

1. Life in Early Louisville

2. Our City Today

3. New York Yesterday and Today

4. A Study of Records

5. Aviation

6. Architecture 
7. Toys

8. A Study of Foods

In applying the criteria for evaluation as a measure to these activities as curriculum materials, they seem to fulfill the requirements set. Any one of the above units may be analyzed to show that it satisfies the criteria from the standpoint of interest, thinking, endeavor, social development, participation - in fact, all the desirable learning situations may be present.

In the primary grades, the instinctive interests and capacities of the children seem generally to have recelved the greatest consideration. The natural activity of all chlldren is especially dominant in the younger ones. Physical, mental and emotional activity is strikingly evident. In selecting the units for the children of the primary grades in Finzer School, these interests and activities have been constantly kept in mind. A few of the units follow:

1. Setting a Hen

2. The Dairy Farm

3. Pets

4. The Play City

5. Indian Life

6. Children of Other Lands 
7. Community Helpers

8. A Cafeteria

In checking these units as curriculum material, with the criteria as a measure, they seem to be meeting the needs required. This means only that satisfactory units are being provided, and does not mean in any sense that all desirable educational objectives are being fulfilled or that the educational method is what we could wish in a large number of cases. 


\section{- . CHAPTER VI}

PERTINENT FINDINGS.

-

IN

PREVIOUS INVESTIGATIONS 
CHAPTER VI

\section{PERTINENT FINDINGS IN PREVIOUS INVESTIGATIONS}

It is interesting to note, in reviowing the literature, the number of studies, investigations and magazine articlos that are concerned with the activity program in the public schools. Some of these point out the difficulties oncountered in the introduction of progressive practices Into the public schools. Others point to trends in modern education and the influence of the activity movement upon educational practices. Others deal with the evidences of growth and desirable attitudes which are outcomes of this type of teaching, and yet another group evaluates the movement objectively by scientific appraisal.

In former years the literature in this field recointed largely the experiences and activities of private and experimental schools. It seemed to be the consensus of opinion among public school people that progressive education was for the elect and not for the masses; that necessary materials and equipment could be had only at such cost as to make their use prohibitive; that large classes of public school size precluded progressive procedure; and that under such teaching pupils would fall to gain proficlency in certain sk11ls and knowledges that seemed to be excluded from the activity program. 
Only rarely can one find evidence, in printed form, of progressive procedure in education in the public schools as long as twenty years ago. It was extremely gratifying to find one account of this ploneering spirit in an article written by Sidney G. Firman on Taking the First Steps in Progressive Education. Mr. Firmen was superintendent of schools in Glen Ridge, New Jersey, at that time and he calls his first efforts in the direction of a socialized curriculum as "Iittle more than an increase in freodom." 2 However, It gave the pupils "an opportunity to direct their own activities and gave some preparation for social living. ${ }^{3}$

He lists further stops in his carrying out of the socialization of class work. Among these was the use of class groups, and the removal of desks in the primary departments with the substitution of tables and chairs. Later procedure Included graded group-assignments to care for individual differences, and various study techniques to provide broad and meaningful educational experiences rather than the narrow, formal learing of the traditional type.

Mr. Firman holds the lack of materials of instruction as the greatest handicap to progressive teachers. He cites the inadequacy of textbooks and points out that in spite of this,

1. Fimman, Sidney G., "Taking the First Steps in Progressive Education", Progressive Education, pp. 30-34. January, 1935.

2. Ibla., p. 31 .

3. Ib1d., p. 31 
American teachers are sald to depend upon them more largely than any group in the world.

He cautions teachers to progress slowly in changing from traditional to progressive education. Much of the fallure of accomplishing their purpose has been the sole result of teachers attempting too much, and undertaking it too abruptly.

He emphasizes that his purpose in this article has beon to suggest methods whereby teachers who hope to institute a full progressive program ultimately, may be encouraged to take the "firat steps."

In 1931, Dr. Laura Z1rbes published the report of a study she had made of the status of progressive education in the elementary schools. ${ }^{1}$ since Dr. Zirbes onumerates forces and circumstances that she belleves are hindering the inftiation of the activity program in the public schools, it is important that we consider her findings. She believes that the following factors are noteworthy deterrents:

1. Vested interests which are antagonistic to anything that threatens royalties, sales, prof1t, prestige or power. 2. Inertia and Innate conservatism which oppose any significant deviation.

1. 21rbes, Laura, "The Status of Progressive Schools", Progressive Education, pp. 359-366. May, 1931. 
3. Over-enthusiastio radicals who exaggerate certain elements and over-emphasize the se to the entire disregard of others.

4. The training handicap of the traditional teacher.

5. The lack of suitable teacher training material to furnish guldance in the practice of progreasive ideas.

6. The Inadequacy of traditional elementary textbooks and other materials which are ased in pupil gixidance.

7. The inadequacy of equipment and also the plan of the school buildings.

8. The traditional standards and concepts held by parents, lay patrons and school boards.

9. The confusion caused by leadership of supervisors or administrators holding diverse views.

10. The lack of consistent direction and gidance.

11. The serfous mistake of attempting too many innovations simultaneously.

12. The laok of a body of reliable data which adequately represents the new movement and which may be used to challenge the respect of the conservatives.

Although Dr. Zirbes has struck at the very heart of the difficulties which confront both teachers and administrators in the public schools, these difficultios seem to have offered a challenge to those educators who were Imbued with the new apirit in education. 
Edna R. Mejers writes of an experiment launched in Chlcago in the summer of $1931 .^{1}$ A traditional summer school, located in typlcal c1ty community, was reorganized on the basis of progressive education practices. The purpose of the experiment was to develop progressive education in a public elementary school. It was hoped that gradual appl1cation of the experimental phases of education might be applied to other schools in the system through this initiation.

The school was divided into six groups of thirty pupils each, corresponding to the first six grades of the traditional school. A teacher had charge of each group in an Integrated home-room program which was based upon social studies and science. Roading, spelling and arithmetic wore adjusted to individual neods. Special teachers of art, rhythm, industrial arts, and out-door play were included in the staff.

By the end of the first session, the signs of growth and development were so evident that it was decided to continue the school during the regular term as an experimental school. A second school was opened in September of the same year (1931) with the same type program.

1. Meyers, Edna R. "Experimental Possibilities in the Public Schools", Progressive Education. pp. 22-28. January, 1932. 
Hookett, ${ }^{1}$ in writing of the activity program in intermediate grades, points out certain standards and objectives which he belleves should be achleved by teachers through their activity programs. He emphasizes:

1. Cultivation of the scientific spirit.

2. Development of constructive individualism.

3. Integration of personality.

4. Growth in freedom.

He discusses each of these objectives briefly and then points to the standards that we must set to evaluate our progress. These, he says, must be personal, flexible, dynamic, cumulative and progressive.

It is interesting to note that these objectives and standards which Hockett holds to be so basic, are included, in effect, in a study made by Willard $W$. Beatty in the evaluation of the contribution of experimental schools, both public and private, to American education.

Beatty, 2 Superintendent of the Bronxville Public Schools, made a survey of fifty-six elementary or secondary schools In the spring of 1932, as a representative of the General Education Board. The survey was made for the purpose of determining how the schools were meeting the challenge of

1. Hockett, John A. "The Activity Program in the Intermediate Grades: Objectives and Standards", Education, pp. 471-476. Apr11. 1932.

2. Beatty, F1llard W. "Progressive Education in the Public Schools", Progress1ve Education, pp. 467-472. November; 1932 
a changing civilization. He drew general conclusions from his whole trip, and foremost of these is the influence of the truly experimental schools upon the educational thought and practice of the public schools.

Other conclusions discussed rather fully include:

1. The lack of direct relationship between the money invested in a physical plant and the educational results achleved.

2. More intelligent use of modern objective methods of measurement in experimental than in traditional public schools.

3. The importance of creative and effective leadership in the productive contributions of the schools visited.

4. With a fow exceptions, the lagging behind of laboratory schools in connection with teachers colleges and universities, to a greater degree than the public schools which they serve.

5. The contribution to education of the mental hygiene movement in effecting a tremendous change in teacherpupil relationships in schools of all types.

6. Greater restraint and moderation in personal behavior among high school students, due to the granting of greater Preodom.

7. The holding of two radically opposed views by the educational leaders of the schools visited. One group held 
for the development of the individual by allowing him every opportunity to follow his natural bent. The other group held that to allow a gifted child to develop major Interests at the expense of portions of the prescribed curriculim was inconsistent with the purpose of the American public school.

8. The interest shown by schools of all types in the creative expression of children in art and language.

9. With fow outatanding exceptions, the lack of effective work in the social studies to prepare children for adfustment to our changing social conditions and for training in citizenehip.

10. The great advance of the elementary schools over the high schools in acceptance of 1deas which have brought many and radical changes in their programs.

11. The change in student government organizations which $1 \mathrm{~s}$ taking place in schools like the North Shore Country Day and Bronxville, where the question is being asked: "Why should schools persist in indoctrinating adult patterns whose services to manking are being severely questioned by well-qualified authorities?"

12. The relatively slow acceptance of desirable modifications of school procedure. Certain outstanding schools have difficulties which are keenly sensitive to the findings of acientific education and make a sincere effort to 
profit by their use. The public schools and another small group of private and laboratory schools, whilo almost as sensitive. to educational research, are handicapped by a lack of systematic provision for keoping in touch with such research so that evaluation of desirable procedure may be made and incorporated into their programs.

13. The 1mportance of the reorganization of normal school and teachers college curricula to meet the new educational demands made by the rapld spread of progressive 1deas and methods into the public schools.

This last conclusion of ih. Beatty was so generally conceded to be of paramount importance that a committeo was appointed in the fall of 1933 by the Progressive Education Association to consider it as a problem to be solved. Dr. Laura Zirbes was appolnted Chairman of the Committee on the Training of Progressive Teachers. 1 Thls group was asked to consider the development of progressive practices in the training of teachers, the collection and dissemination of information helpful to classes in teacher training schools, and the encouragement of scientific studies for the analysis and evaluation of progressive education. Furthermore, this

1. "News of the Association", Progressive Education, p. 435. November, 1933. 
committer was asked to investigate and re-interpret the state requirements in education for the purpose of fostering experimental approaches to teacher-training problems.

Somewhat along this same line of thought is Agnes Snyder's discussion of the inauguration of the activity program in the Intermediate grades. I Miss Snyder stresses the teacher's preparation, but she places her emphasis upon e loar and definite knowledge of fundamental understandings essential to the control of behavior. Some of the se understandings are concerned with the practical affairs of life, some have to do with natural phenomena as Interpreted by science, others deal with social relationships and finally, there are those understandings which are the ultimate outcomes of experience, and so determine fundamental attitudes. The next step toward the fulfillment of the program as she outines it, is the acqualntance period in which the teacher makes group and individual contacts with the children. Step three calls for the year's plan - both class and Individual. Too much emphasis cannot be placed upon the Importance of thorough knowledge of the conditions by both teacher and chlldren before planning can be properly begun, sho says.

1. Snyder, Agnes, "The Activity Program in the Intermediate Grades: Its Inauguration", Education, pp. 476-482. Apri1, 1932. 
Preparation for work is next considered and this calls for a detalled study of all possiblo resources. Included in this study are the need of materials, how they may be procured, filing devices for references, and the allocation of work.

The final step is the carrying forward of the work. This calls for planning and experlencing of teacher and chlldren. Experiences are recorded and new plans are made. The inevitable widening of children's interests lead into new and broader relationships.

A most significant analysis of trends in elementary oducation is recounted by Claire Zyve and Marie Merrill in the Jamuary, 1934, Teachers College Record. ${ }^{1}$ The investigation is of particular value in connection with this study because it analyzes the results of the newer practices in education. The findings were secured as a result of a very unusual type of cooperative research carried out as a part of the program of the Informal Teaching Commlttee of the New York Principals' Association. Approximately three hundred teachers and two hundred principals participated in this work.

The commlttee secured, during 1932-1933, descriptions of 452 units which had been, or were at that time in progress

1. Zyve, Claire and Merrill, Marie., "Analysis of Trends in an Informal Unit Teaching Program", Teachers College Record, pp. 293-309. Jenuary, 1934 . 
In classrooms. In response to questionnaires, data from 788 additional units were secured. A committeo of classroom teachers aided the Informal Teaching Committee in an analysis of the manuscripts to discover trends in classroom procedure which seemed to accompany the unit type of teaching. Outstanding trends were noted and a brief discussion of each trend given.

The trend listed as most conspicuous was "Opportunities for Soctal Experiences". The expression of the children's own needs in their classrooms, shown by their arrangement of the furnfture, flowers, collections and exhibits, spoke of normal living in school. The ingenuity and variety in the use of materials was noted. Cooperative room and school activities were the general rule.

"Social and Economic Interpretation of the Community" was pointed out as a significant trend. It was rocognized in the welding of the school and the community through the development of soclal and economic understandings. There was definite tendency toward greater utilization of opportunities for first hand experiencing in each community.

The third trend was called "The Drill Program". There was shown to be the tendency to include with the activity only such drill as has functional use. Soparate drill perlods have been the result of this tendency. Of the 156 teachers in grades I-VI, who answered the questionnaire on 
this subject, 136 sald that they included short drill periods in spelling, arithmetic, grammar, writing and reading. In grammar and writing, these drill perlods averaged 9 minutes a day, and in reading and arithmetic, 23 minutes a day.

Another Important trend, "The Integration of the Separate Subjects", was shown in the shift of separate subfects from isolated positions to those of tools for use in the solutions of problems. Subject matter and time divisions were shown to be disregarded in the carrying out of activity programs.

"The Use of Books for Reference" was next listed. A definite trend was shown for children to use books to obtain information, and for them to bulld up certain research attitudes and techniques. As many books as possible were used for the problem under investigation, while texts were used largely for such drill subjects as required the use of fentical facts.

The final trend, "Growth in Teachers", was emphasized as the tendency for teachers to acquire the techniques that they are working for in the chlldren. They were shown to be making critical analyses of their work, compling bibliographies and making lists of materials and supplies for future use. They also advocated making wider use of the materials of the immediate community and suggested other 
leads from the activities experienced.

These trends were held to be highly important in their revelation of significant implicetions: The emphasis upon human relationships, the changing status of the school from a show of itself to a community participation in $8 \mathrm{chool}$ enterprises, and the provision of the informal curriculum for children to develop at different rates and in different directions were some of the implications mentioned.

One of the most comprehensive studies bearing upon the activity movement in the public schools is the investigation made by Dr. Fay Adams which she has recently published: The Inltiation of an Activity Program into a Public School. In this study, Dr. Adams has undertaken to obtain facts about the difficultios involved in inftiating an activity program into a public school. She has limited her study to three aspects of the problem:

1. The discovery of major difficulties encountered by teachers in attempting to initiate an activity program.

2. The determination of some solutions of these difficulties. 3. The eraluation of the relative desirability of these soIutions.

She assumes that the activity program is worth-while and that its introduction into the public school is highly

1. Adams, Fay ., The Initiation of an Activity Program into a Public School. Burean of Publications, Teachers College, Columbia University, New York City. 1934. 
desirable. She became aware of the difficulties oncountered by teachers in introducing such program into their classes while she was directing a class in elementary methods in the University of Southern Callfornia. She then declded to make a study of the problems involved.

Ninety teachers who had had experience with the actirity program listed difficulties which they considered outstanding. These lists were carefully checked with units of work, courses of atudy and current literature so as to make sure that no 1mportant problem had been overlooked. A 11 st of 28 major problems was thus secured. Each problem was then rated according to 1 ta difficulty by a group of 109 teachers, supervisors, and administrators. From this rating, and a discussion with numerous persons who had had extensive experlence with activity programs in public schools, Adams determined upon ten problems for further study. They are:

1. The problem of learning how to select and develop an activity.

2. The problem of tosting the results of the activity.

3. The problem of maintaining a desirable working atmosphere during the unassigned period and at the same time encouraging individual freedom and initiative.

4. The problem of planning a time program which can be effectively used in developing activitios.

5. The problem of adjusting an activity to meet the individual differences of the pupils. 
6. The problem of finding the proper reading materials to aid the children in solving their activity problems.

7. The problem of finding other materials necessary in tho development of an activity.

8. The problem of securing the cooperation of the principal, superintendent or other administrative officers not entirely in favor of an activity.

9. The problem of austaining the interest of the children daring the development of an activity.

10. The problem of dereloping an activity and at the same time meeting the course of study requirement for the sk111 and drill aspects of the curriculum."

When these ten major alfficulties had been decided upon. the next step was to find possible solutions. Four sources were used in this connection: experienced teachers, profesalonal 11terature, the personal experience of the author, and specialists with extensive experience in activity work. After the solutions had been obtained, the next atep was an evaluation of their relative desirability. This was accomplishod by sending a questionnaire which contained the ten difficulties and their solutions, to persons who had studied and experimented with the activity program. This group included teachers, administrators, aupervisors, and opeciallsts, and through their cooperation 949 questionnaires were used for the final study. 
An entire chapter (Chapter IV) is given over to a discussion of the conclusions of this group. A five point scale was used and the solutions grouped under the followIng classifications: excellent solutions, good solutions, solutions having little merit, solutions having some merit, and undesirable solutions.

Adams belleves that these findings will be valuable to supervisors, administrators, and teachers who, in developing an activity program, may find possible solutions to difficulties. It should also be helpful as a basis for discussion for groups who are studying the activity program in colleges, universities or normal schoors.

Keliher, Supervisor of Elementary Education in Hartford, Connecticut, holds the same convictions of Adams in regard to the importance of progressive practices in the public school. In the March, 1935 issue of Chlldhood Education, Heliher discusses progressive education in it relation to the public school. She raises general questions which are largely answered in the light of tested performance.

In answer to the question, "Is a change in public school education necessary?", Kellher says that it is not only necessary but ineritable. She cites many instances to show that education must move on with the times: the inaccuracy of maps; textbooks facts which have long been disproved;

1. Kellher, Alice V., "What About Progressive Edncation?" Chlldhood Education, pp. 243-248. March, 1935. 
discarded superstitions; and learnings least effectire for creative and critical thought.

"What scientific basis is there for the contention that education should move torard the activity movement or progressive education?" An analysis of the basic sclences of human growth - b10logy, phy810logy, hyglene, and psychology emphasize development through activity. Since the progressive program grows out of the basic facts of the sciences of growth, and since 1t mores with, rather than against thom, the activits program 1s fundamentaliy scientific.

"Is there a single method or technique of progressive education?" Since there is the greatest possible variation In communities, schools, grades, and individual problems, there cannot be the same method applied. The needs of each school must be analyzed, met and provided for, if the program is to function adequately.

"Should one attempt to introduce an activity program all at once?" Teachers must understand and believe in the activity program if progress is to be made. The public school should not fump ahead of its teachers, and teachers should not be forced into an acceptance of practices in which they have no faith. The progress will necessarily be uneven and will reflect individuel teacher growth rather than mass accoptance.

"What kind of discipline does the progressive school 
foster?" The progressive school holds that freedom and Independence are essential for survival today, but that these come only with well-ordered living and must not be confused with irresponsibility, 11 cense and vacillation. The progressive teacher works for adequate standards of behavior because these are essential to growth.

"Does the progressive school develop real scholarship?" If the activity program is properly executed, real scholarship 18 achioved. Where scholarship has suffered in progressive schools, it is because the swing from the old subject matter type of learning has been so severe that a proper balance has not been malntained. The progressive school puts the emphasis upon the use of all possible sources for Information and knowledge. This frees the child from the fetters of textbooks and courses to the extent that he may develop as great a degree of scholarship as he is capable of acquiring.

"Does the progressive school teach the sk1ll subjects?" The progressive school does not repudiate the teaching of the skills. However, they make two changes in their teaching of them. They do not teach the skills unt1l the children are ready for them. Here they are guided by scientific findings in regard to readiness. Then, they have learned through recent experimentation, that various processes are too complex for children of certain ages. In such cases, 
the teaching of these skills is saved until the age level at which children can learn them readily and w1thout confusion. Furthermore, the progressive school endeavors to teach the skills in such relationships that they have meaning to the children.

"Have these things actually been proved in practice?" In answer to this question, the classroom activities in a mall progressive public school which is used as demonstration center for Alabama College, are listed for a perlod of one week. The creative and appreciative activities, the reading, the number concepts, English, spelling, geography, history, and sclence outcomes are 11sted. The great varlety of rich experiencing shown in these 11sts, and the sk111s, habits and attitudes acquired give definite proof of these values in practice.

While it 18 entirely outside the scope of this paper, as stated in the Introduction, to make a quantitative measure of the activity program, or to draw any conclusions as to the relative merits of the progressive versus the traditional type of teaching, several significant studies have been made in the last few years for the purpose of measuring the curricula of the activity schools. Although there 18 a difference of opinion as to how accurately the intangible outcomes of an activity program can be measured, certain appraisals have been made which seem to refute the accusation 
of unsuccessful measurement.

In June, 1933, Hopkins ${ }^{1}$ published a report of a study made in the elementary grades of the IIncoln School. While he questioned the validity of objective subject matter examinations as applied to activity curricula, results showed the objections to be unfounded. Stanford Achlevement Tests were used and a comparison made with the scores of pup11s In corresponding grades in the general school population. It wa found that the pupils in the Ifncoln School had slightly higher medians in reading, arithmetic, spelling and composite age.

Meriam ${ }^{2}$ reported a study in June, 1933, of an activity school for Mexican children, located near Los Angeles. The curriculum consisted of three subjects: play, stories, and handwork. He measured the essentials learned by using the Detrolt Reading Tests, the Ayres Handwriting Scale, and the New Stanford Arlthmetic Tests. The chlldren were found to be close to the norm of American schools in the three R's, and that the progress in months was most signiflcant. Collings, in June, 1933, reported the results of a comparison made of the achlevement of pupils in the University

1. Hopkins, L. Thomas, "Loarning Essentials in an Activity Curriculum", Journal of Experimental Education, pp. 298-303. June, 1933.

2. Meriam, J.I., "An Activity Currioulum in a School of Mexican Children", Journal of Experimental Education, pp. 304-308. June, 1933.

3. Collings, Ellsworth, "Loarning the Fundamentals in the Activity Curriculum", Journal of Experimental Edncation, pp. 309-315. June, $193 \overline{3}$. 
of Oklahoma Junior High School, an activity school, with that of a comparable conventional junior high school. The results, based upon a battery of 13 tests, showed that the pupils in the activity school did as well or better than the puplis in the conventional school.

In June, 1933, Howe 11, Dunn and Stoker published a study made of the learning of fundamentals in an integrated curriculum program. The observations rere made in the Roosevelt Elementary Demonstration School of Long Beach, California.

Approximately one hour of the school day was deroted drill unrelated to the major interest. The New stanford Achievement Tests were used as a check in this study, and it was found that all classes, including the slow moving groups, wore up to the standard educational age or near the standard of pupils in general.

A more informal, but highly signiflcant appraisal of an activity program is that recorded in Western Youth Meets Eastern Culture. 2 This book is a report of an integrated curriculum for the seventh grade. It 1 s shown that the

1. Howe11, Etta; Dunn, Mande $W_{0}$; and Stoker, Dora., "Measuring the Skilis in an Integrated Program", Journal of Experimental Education, pp. 3n6-310. June, 1933.

2. Sweeney, Frances; Barry, E.F.; and Schoelkopf, A.E. Western Youth Moets Eastern Culture. New York: Teachers College, Columbia University, pp. 192-245. 1932. 
pupils made gains in fundamentals, although the authors declare the limfted value of objective tests for the mastery of essentials. They discussed in detall the children's accomplishments in study and work habits, use of source materials, examination of data, organization and reporting of facts, courtesy in the interchange of opinion and in the cultivation of social attitudes.

L. W. Smith, ${ }^{1}$ superintendent of Schools in Berkeley, California, reports a critical evaluation of the activity program carried out by the schools in his city. He points out that, while no factor in the educational program could be less subject to quantitative measurement than the procedures of an activity program, 1t is the duty of a school systom to make check of the actual educational service rendered by such a program. Accordingly, be made an evaluation of the Berkeley public schools activity program by means of a questionnalre study. A careful definition of Activity was included in the questionnaire to guide teachers in making responses. This definition was prepared by the supervisor of elementary instruction, who is in responsible charge of classroom procedurea. The definition follows: "An activity is an enterprise organized by a pupil or a group of pupils, under the leadership of the teacher, to

1. Smith, L.W., "A Quantitative Study of an Activity Program", Elementary School Journal, pp. 669-677. May, 1933. 
further classroom study. Such an activity requires purposing, planning, evaluating, deciding, selecting, eliminating, organizing, constructing or creating. It lmplies soelng, hearling, expressing, doing, and appreclating, and affords opportunity for the child to acquire information, weigh values, make decisions, develop attitudes, and make behavior responses in connection with real situations."

The questionnalre was sent to all elementary school teachers in the spring and fall. The tabulations ind1cated that the social studies were the most fertile sources for the inftiation of activities. However, once the activity was started, art was more frequently concerned in its development than any other subject. In compliling the data, It was clearly shown that art, langrage, reading, and the soclal studies were the most important of all the subjects involved in an activity. None of the other subjects was involved in as many as one-half the activities mentioned. such important formal subjects as penmanship, spelling and arithmetic belong in the latter classification, it was brought out. Particular attention was directed to the fact that ar1thmetic was involved in less than one-fourth of the activ1ties.

The conclusion was drawn that activities along cannot be dopended upon for developing a well-balanced educational program in the elementary school. However, no data were 
presented based upon tests of mastery.

A most significant and forward-looking step in the appralsal and comparison of progressive with traditional schools is set forth in Dr. J. Wayne Wrightstone's ${ }^{l}$ monograph wh1ch 1s fust off the press. Dr. Wrightstone was selected by the Institute of School Experimentation, Teachers College, Columbia University, to consider the problem of adequate measures for those desirable quallties of personality, reaponsiveness, cooperativeness, and dependability for whlch there had never been avallable tests or measures. This was, however, only one phase of his study which he calls "a ploneer attempt to make a partial appraisal of study programs and teaching practices in a fow selected newer-type prablic schools". The findings are result of an intensive two year study financed in part by funds provided by John D. Rockefeller Jr. The General Education Board has made a grant to continue the study for two more yoars .

Four communities cooperated with the research workers in the administration of tests and other measures reported in this study. The conditions and populations of school children used represent cross section of average canditions

1. Wrightstone, J . Wayne., Appralsal of Newer Practices in selected Public Schools. Bureau of Publications, Teachers College, Columbia University, New York City. 1935. 
In representative cities and villages in the Unfted stater. Financial restrictions limited the sampling of both communities and pupils and the author readily admits "that other studies which include more raried and nation-wide samplings may extend and modify the findings of the present study of newer practices in selected public schools".

The study is concerned with the measurement of the results of the teaching in two types of schools, upon the pupils in scholastic achievement and in personality. The old-type elementary schools, chosen for the experiment, adhered rigldiy to the memoritor and textbook plan, with all pupils reciting on identical assignments. The ner type, or progressive elementary schools based their work about centers of interest, projects and problems of living in which there was purposeful experiencing.

The same comparison was made in the high schools. The old type high school was checked against the progressive high school, in which the course of study was reconstructed. In the reconstructed course, social studies unifies history and civics with particular emphasis upon current social and economic problems. The natural sciences draw upon the fields of biology, physics, chemistry, geology and astronomy to find solutions for problems which are presented. In the languages,

1. Ib1d., p. 3 . 
the emphasis is placed upon the ability to read widely and eas1ly, and to make better oral use of the language, rather than upon a memorization of formal grammatical rules.

Three factors were used by Wrightstone as a classification basis for his appraisal. These he designates as first, Intellectual factors which deal with mental content and skills; second, dynamic factors which include wishes, motives, attitudes, and opinions; and third, performance factors which consist of controlled observation of classroom performance and behavior.

He equated his groups of the two types of teaching practice by a matched palis technique, using intelilgence quotient, chronological age and soclo-economic status as the three bases. A battery of tests was used to measure the skill areas of reading, spelling, language and arithmetic. In the lower elementary grades, no effort was made to measire the dynamic factors but in the upper elementary two questionnaires were administered - one on activity, and another on independent methods of work.

All grades were measured on the performance factors in group discussion and recitation by a controlled-observation technique. This necessitated a dalis sampling of class discussions, group discussions and recitations to determine such outcomes as initiative, curlosity, 
responsibility, criticlsm and memory. A pupil was credIted with inftiative if he made a voluntary contribution, suggestion or report; with curlosity, if he asked questions and sought Information; with criticlsm, if he praised or challenged a statement; and with memory, if he responded to the traditional question on a prescribed textbook assignment.

The appraisal of secondary school practices was identical in procedure with that for the elementary school with the exception of the dynamic factors evaluation. In the secondary schools, personality, attitude and character testa were used, and in the dynamic factors category were included beliefs, attitudes, motives and opinions.

A. a result of these various tests, interesting findInga were brought to light. It had been expected that the first three primary grades of the progressive schools would show up badly because of their lack of textbook drill. However, they showed distinct superiority in reading, spelling, language and arithmetic. They scored six points higher than pupils in the traditional schools in reading, four in spelling, seven in language, and throe in arithmet1c. Progressive school chlidren malntained their load in the upper olomentary grades and in the high schools, where they were shown to be equal or superior in all subjects except intermediate algebra. Graphs accompany these Interpretations 
of test results.

In making an analysis of attitudes and beliefs, it was found that pupils in the new chools were more liberal minded and scientific on such problems a race relations, International affalrs, national politics, and national cultural achlevements. They were also shown to possess superior attitudes and beliefs on problems in natural science. Ittle difference was shown between the two types of schools in the results of tests in personal and social adjustment, with the one exception of honesty, which was shown to be greater in pupils of the new schools in a self marking test.

Wrightstone concludes that the "evidence may be interpreted as tentative proof of the validity of the educational theory and principles upon which the newer type practices in the selected schools are established". 1

\section{SUMMARY OF THE INVESTIGATIONS}

Certain conclusions may bo drawn from an evaluation of the studies considered and the following observations seem pertinent :

1. Progressive schools are exerting more and more influence upon the educational thought and practice of the public school.

1. Ib1d., p. 116 . 
2. Educators who are in whole-hearted accord with the activity program in the public schools, urge slow transitional process when newer practices are being incorporated into traditional schools.

3. Great ingenuity is shown by administrators, supervisors, teachers and children in providing for and securing materials which may be used in the classrooms.

4. There 1s a general foeling of a great need for materials of instruction sultable for use in activity work in the public schoole.

5. An increasingly greater number of public schools are emphasizing the social phase of education which has always been employed by the progressive group.

6. The principle of integration is shown in the shifting of separate subjects from isolated positions to those of tools for use in solutions of problems.

7. The principle of growth in child development has superseded to a large degree, the old doctrine of subject-matter-to-be-learned.

8. There is general agreement as to the need of incorporating the implications of the new education into materials for the guidance of teachers in service. There should also be reorganization of the curricula of teacher-training institutions for the better 
preparation of prospective teachers.

9. Research investigations refute criticlams of the achievement outcomes of the activity programs. A comparison of pupils in conventional and activity schools was made in numbers of investigations. It was found that the pupils in progressive schools performed as well or better than the pupils in traditional schools.

10. A comprehensive investigation for testing the validity of progressive educational theory and practice has disclosed significantly positive findings.

11. The activity program of the elementary school presents a challenge which cannot be ignored.

The results of the general experience as reviewed in the literature on the subject of progressive education in public schools coincide singularly with our experience in the Nicholas Finzer School. The slow transitional process so generally urged in the initiation of an activity program Into a public school has been our method of procedure. The difficulties of adjustment to physical handicaps and the problem of securing materials have been experlenced. A consideration of the need for guidance and in-service training of teachers has been recognized. The achievement outcomes of the pupils (obtained by standard tests) has been $a 3$ good as, or better than that of pupils in comparable schools. It may be sald that generally the sallent features of experience throughout the country have been identical with our experience in the Finzer School. 
CHAPTER VII

A PLAN FOR THE FUTURE 


\section{A PLAN FOR THE FUTURE}

In looking forward to a fuller realization of the activity program in the Nicholas Finzer School, it is important to consider what plans should be made.

In the first place, a brief recapitulation of past experiences and present conditions may not be inapropos. During the last twelve years there has been a determined and persistent effort to lay situations and provide opportunities for the incorporation of life experiences into the course of study. A working basis has now been established throughout the school. As has been pointed out, this does not in any sense mean that our limitations and dificulties have been overcome. It merely means, that on the whole, the teachers have grown in the philosophy of the new education. They have accepted the theory of the unit as curriculum material, although with the exception of the primary grades, the unit does not embrace all the teaching of all the subjects. In the primary grades, the unit does become the curriculum and reading, spelling, number work, geography, history, language and science are not considered - the whole day centers around the activity. In the intermediate and upper grades, the unit still is considered the core of the curriculum, but 
other subjects are taught separately. For instance, the history, geography, English and art usually are very closely interrelated in these grades. However, the arsthnet1c is taught as a separate subject, except in those cases where it actually touches the activity, as in counting, measuring or computing. Spelling, penmanship and music may or may not be a related part of the unit. It should be said here, that much depends upon the skill and understanding of the particular teacher. One teacher may effect a much closer correlation of subject matter than another in an almost identical situation.

Evidence of the growth in teachers' thinking is seen in their general acceptance of the fact that subject matter should be integrated. Here again, the greatest strength may be seen in the primary grades. In the intermediate and upper grades, the integration is effected to a certain degree, but it stops short of a perfect whole. This is seen in the isolated teaching of arithmetic and spelling, for instance, and the integrated teaching of history, goography, English and art.

In looking at the whole picture, it may be said that while the teachers in the Finzer School have grown in an understanding of the basic principles of integration 
and teaching through experiencing situations, they are still thinking in terms of subjects and formal skills. Again, it must be pointed out that this statement is not true of every teacher, but it is true of the group.

In this connection, it should be noted that we have been helped in the unit plan procedure by the general attitude of those responsible for the determination of the course of study in the schools. For several years, curriculum revision has been under way with the newer objectives in education in mind. As a result, a modified unit curriculum has emerged. The unit has now come to be generally accepted as the core or the center of Interest in a grade. It has gone far on the road to integration and breaking down rigid time schedules in the elementary school, but it still calls for subject matter teaching. It is this that necessarily controls the fuller acceptance of the true progressive procedure in our school.

In thinking of the next steps in the educational program of the Finzer School, certain objectives loom large. In the first place, there must be a richer subject matter background for the teacher. She should have at her command such materials as will give her a veritable saturation of the subject matter content. 
This should also include every avallable type of pictorial material, as well as actual source material or suggestions how to secure this material.

Several possibilities are seen for the accomplishment of this purpose. The most fruitful, from the standpoint of teacher growth, is the working out of several units by each teacher as a year's undertaking. When completed, such units would include procedures, a full subject matter overview, suggested activities showing every possible interrelationship, source materials, and full bibliographies. These units would be worked out with the chlldren and records kept of discovered strengths and weaknesses. These could be pointed out or corrected as the work progressed. At the close of the year, each unit, properly labeled, would be filed for reference and become source material for the school. By a continuation of such a procedure, a library of units, rich and exhaustive in content, could eventually be established without working a hardship upon any one teacher and actually providing excellent opportunity for growth.

The following outline suggests a working basis for a teacher to follow in assembling these teaching materials. This outline may be used for any unit: 


\section{THE ASSEMBLING OF SOURCE MATERIALS}

1. Make list of lantern slides, applicable to unit, which are already in the school.

2. Make supplementary list of slides which should be purchased.

3. Make Iist of pictures, applicable to unit, which are already in the school.

4. Make a collection of pictures for the unit.

5. Make list of sources where additional pictures may be secured.

6. Make list of magazines, such as National Geographic, Asia, Popular science etc. (give specific issue) which may be used as teaching materials, if applicable to unit.

7. Make a collection of travel pamphlets, if unit permits their use.

8. Make list of references to art books which give suggestions for the unit or work related to it.

9. Make a diagram or working drawing of any related construction problem, for example, Conestoga wagon, Viking ship, etc.

10. Make sketches of possible room arrangements of such projects as the community, the dairy farm, etc. 
11. Make a list of articles suitable for a museum collection. (Indicate articles already in the school, if such are included.)

12. Make suggestions for bulletin board displays.

\section{SUGGESTED ACTIVITIES}

1. Constructional problems such as, buildings, boats, instruments, etc.

2. Modeling and soap carving - pottery, animals, figures, buildings.

3. Dyeing - old pieces of cloth for rugs, costumes, etc.

4. Painting - pictures, frieze, programs, scrapbook, invitations, lantern slides, shadow pictures.

5. Sewing - Costumes, cloth puppets and marionettes.

6. Weaving - rugs, etc.

7. Block printing - programs, invitations.

8. Writing - stories, poems, riddles, jingles, songs, dances.

\section{CULMINATING ACTIVITIES}

These should be given in detall and not merely listed, for example:

1. Play - Title - "An American Traveler in Egypt"

Scene I.

Scene II. 
2. Movie - give brief description.

3. Talkie - tell how it would be worked out.

4. Exhibit for parents - give plan.

5. Assembly programs - list and explain, for example, shadow pictures

illustrated talks

plays - tableaux

rhythms and games

\section{BIBLIOGRAPHIES}

1. Make list of books already in school which are applicable to unit. (Use office card catalogue of supplementary books.)

2. Make list of magazines in school which are applicable to unit.

3. Make list of books and magazines in Normal School library which may be used for reference.

4. Make list of books and magazines in public library which may be:

a. Borrowed and used in school.

b. Read in library for reference.

5. Make collection of all free material, applicable to unit, such as railroad folders, rallroad maps, road maps, catalogues, price lists, etc. 
6. Make list of pamphlets and folders procurable at Iow price from certain bureaus, boards of education, departments at Washington, etc. Typewritten copies of the above outline will be distributed to each teacher for her use. She will be urged to make notations or amplications which will improve this for future use. At the close of the year, each teacher will file her units in a cabinet provided for this purpose in the office.

Another possibility for the acquisition of desirable teaching background would be the purchase of materials such as the Compton Pictorial Units. While these are excellent, they do not provide the stimulation and growth in teachers which the actual preparation of a unit entalls. Moreover, they are not applicable to all situations. In many cases no unit is available for the need at hand.

In choosing the units for each grade, the needs of the particular class will be considered. These needs will be determined by an analysis of the children's interests and a survey of the immediate environment. In addition to this, certain controlling themes for the whole school will be considered. Three controls will be kept in mind for guiding the thinking of the teachers, and through them, the children, in every grade from the kindergarten through the eighth. 
These are:

1. Man's increasing interdependence.

2. Man's control over nature for his own advancement.

3. The heritage of the past and 1ts interpretation in the light of changing social conditions.

In planning our curriculum with these themes in mind, we are in no way violating the course of study requirements, since the prescribed course suggests units for each grade which will fit in with such a procedure. Neither are we unmindful of the fact that present and future living with its need for problem solving, critical thinking and adjustment to changing social conditions are of paramount importance. An indication of the provision for experiencing life situations to care for this major objective will be shown in the outline given below:

\begin{tabular}{|c||l|}
\hline \multicolumn{2}{|c|}{ SUGGESTED PROGRAM } \\
Primary Grades \\
\hline Theme & Units to Illustrate Theme \\
\hline Interdependence & The School Cafeteria \\
& Comminity Helpers \\
& The Play City \\
& The Toy Shop \\
The Family & The School Fair \\
\hline
\end{tabular}




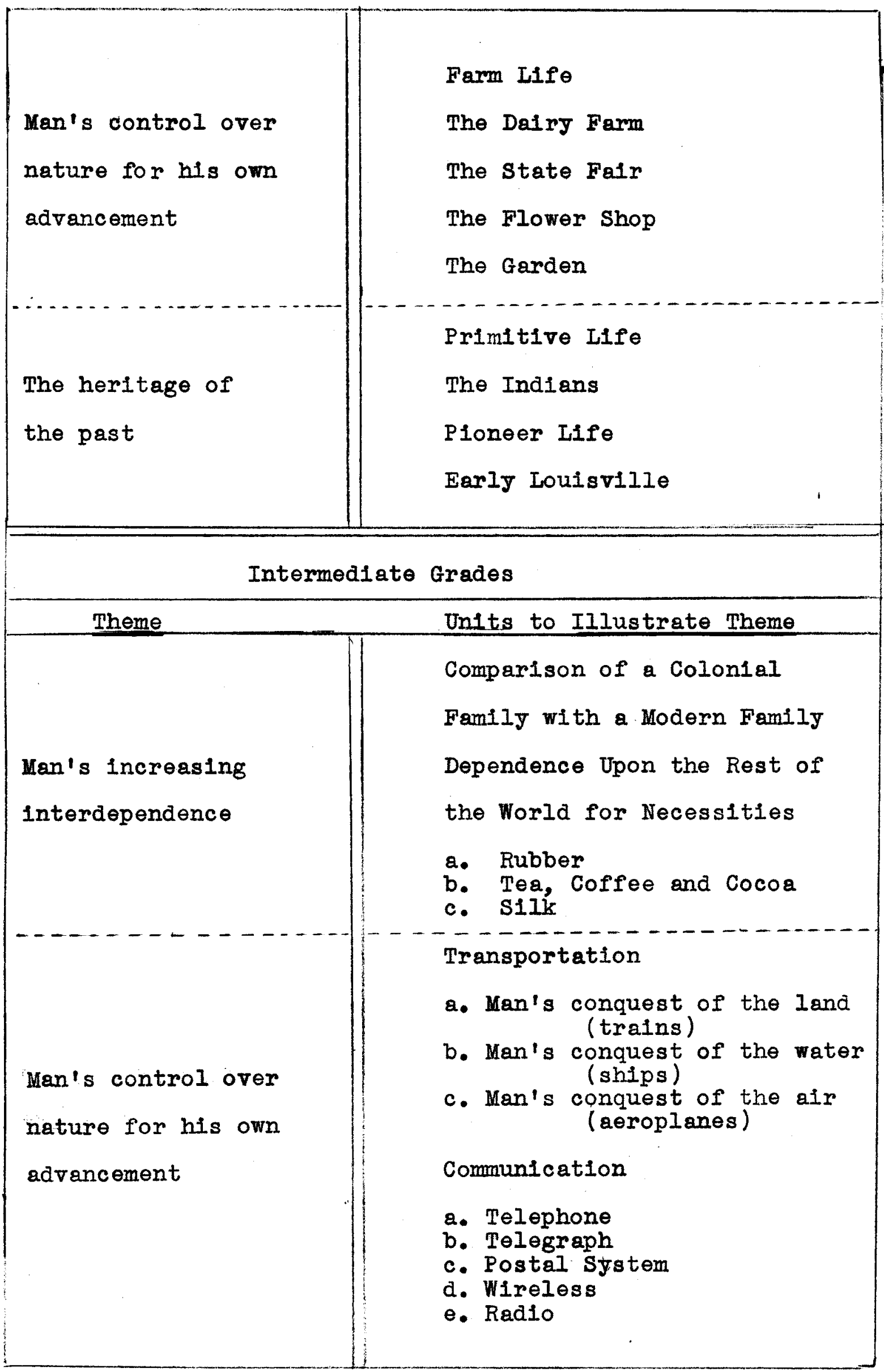




\begin{tabular}{|l||l|}
\hline The heritage of & $\begin{array}{l}\text { The Development of the Alphabet } \\
\text { Paper-making, Books and Records } \\
\text { the past }\end{array}$ \\
\hline Trimitive Weaving \\
Lighting
\end{tabular}




\section{1}

This suggested list of units should not be considered a course of study. It may be that other and better units may fit the particular situation or class. In this case, a substitution may be made. This program has been worked out merely as a guide and as an example of the continuation and integration of subject matter content throughout the school Iife a child. Typewritten copies of this program will be placed in the hands of every teacher, and faculty meetings planned in which it may be freely discussed and criticized.

It is also our plan for next year to have group conferences among the teachers for the purpose of checking on certain needs, errors and attitudes of the children. For instance, after results have been received from the various city-wide testing periods, remedial measures and procedures would be discussed. Graphs might be made to show school and individual achievement in spelling with reference to the norm or an analysis might be made of the language errors as disclosed by the test.

Undesirable social attitudes in certain children would be considered in small rather than in large groups. The visiting teacher or the school nurse might be called in to give a fuller discussion of famliy, health and environmental history. The child's own reaction to the situation would be considered in the working out of a plan for his 
readjustment in the group. A case study plan would be used to indicate the child's needs. These studies would be filed in the office for future use in guiding our procedure.

A closer cooperation between the home and the school has always been a major objective and we are planning the organization of discussion groups as a new venture in this direction. We expect to make these more in the nature of a friendiy meeting ground for a small group of teachers and a small group of mothers, since the educational background of our patrons would preclude a more ambitious program. There is a great opportunity for accomplishment in this direction as whatever is lacking in educational background is more than made up in willingness, cooperation and general feeling of friendliness toward the school. This splendid spirit should be cap1talized for the advancement of the school.

In this same connection, we hope to make greater use of our imediate neighborhood through the bringing in of experts for the school's use. We have done this with admirable results in the past when, for example, a child's father who is a fireman, came to talk to the safety counc1l on fire prevention, and again, when Dr. Lang, a neighborhood veterinarian, served as judge in the school pet show. It is our feeling, however, that we have not 
used our comminity nearly enough; that rich and untapped resources are at our finger-tips.

The same is true of securing source material and first hand information. We are singularly fortunate in the location of our school. Not only are we in the midst of an industrial locality, but we also are near enough to walk to the heart of the business and shopping district, the public library, the post-office, the Memorial Auditorium, the clty market and the Ohio River. Ballard's Mill is within three blocks of the school; Lang's Cat and Dog Hospital is less than one-half block away; Ewing's Dairy and Bradford's Woolen Mills are within walking distance. An interior decorating shop is just across the street, as is also the bank, an automobile supply shop, a battery service station, a florist's shop, a bakery, an electrical supply house and numerous automobile display rooms. While these facilities have always been used for trips, they have not been used sufficiently as source material when needs arose. It is our purpose to encourage children or small groups of children to interview these authorities In the neighborhood or to bring them into the school when problems need to be solved.

It is also a part of our plan to make a card catalogue of these and all other available sources within walking distance of the school. The school district will be divided, so that no part will be overlooked, and different 
classes will be made responsible for listing these community resources. The results will be pooled by each teacher, duplications eliminated, and a final list submitted to the office. These grade lists will then be rechecked to further eliminate duplications and finally each class will receive its corrected list for the making of the cards. The children and the teacher will annotate each card and send these in completed form to the office for filing. A sample card is given:

\begin{tabular}{|c|c|}
\hline $\begin{array}{c}\text { Ballard and Ballard Company } \\
912 \text { East Broadway }\end{array}$ & $\begin{array}{l}\text { Source Material } \\
\text { for following Units }\end{array}$ \\
\hline What may be seen & $\begin{array}{l}\text { Transportation } \\
\text { Machinery } \\
\text { Cafeteria }\end{array}$ \\
\hline \multicolumn{2}{|c|}{$\begin{array}{l}\text { 1. Unloading wheat from trains } \\
\text { 2. The machines at work } \\
\text { 3. Workers in the mill } \\
\text { 4. How the workers are protected } \\
\text { 5. The sanitation of the plant } \\
\text { 6. The cafeteria } \\
\text { 7. The Ballard products } \\
\text { 8. Shipment to all parts of the country } \\
\text { 9. Samples for the school exhibit }\end{array}$} \\
\hline
\end{tabular}

It is our hope to effect a greater freedom in classroom procedure. The two work-rooms that were established this past jear have helped in breaking down formality by the greater possibilities they afforded for moving around, working together and without supervision. It is our ambition to have a teacher in charge of one of the work- 
rooms. This teacher should have a thorough understanding and acceptance of the philosophy of the new education. She would work with the children and with the teachers in securing the best possible interpretation of fine and industrial art as it is manifested in the activities.

Certain equipment would be necessary to carry out this plan. It would include several work benches and necessary tools; a porcelain topped table for clay modeling; several easels; a wash wringer to be used for block printing; a potter's wheel; a hot plate and running water.

In addition to the teaching materials and the survey of community resources, certain other fundamental objectives will be considered. The first of these is the attitude and thinking of the teacher. As has been pointed out, certain steps toward desirable goals have been reached. Rather general agreement of the group is seen on the following beliefs:

1. That the unit type of teaching is desirable.

2. That children learn best in those situations which provide for experiencing and participating.

3. That the children's interest in activities gives a new purpose for the use of textbooks.

4. That certain children have been reached through the activity type of work, and social adjustments made where there were formerly maladjustments. 
The next step is an extension of this thinking and through such extension a greater development of desirable attitudes and outcomes on the part of the children. An effort will be made to secure more meaningful interpretations of situations as they arise. Teachers will be urged to dig more deeply into the fundamental bases. There is at present, too much superficlality and a too easily satisfled attitude on the part of a large number of teachers. A fuller understanding of the real meaning, purpose and philosophy of the activity program will be the greatest factor in changing this attitude.

From the standpoint of the children, much still needs to be done in developing those attitudes and outcomes that we would wish for them. There is great need for socialization in a community of the type in wich the Finzer School is located. Their home and environmental background being what it is throws the major responsibility upon the school. It also challenges the school to extend the children's environment by extensive reading. As has been previously pointed out, a determined effort will be made to develop critical thinking and the ability to weigh all evidence impartially in solving a problem or in reaching a decision. There is a great need for developing desirable moral attitudes. Cooperative activities will be planned with this in mind in the effort to develop 
recognition of the rights of others and respect for the personality of the other members of the group.

Another part of our program includes a better understanding and appreciation of the work going on in the different classrooms. Intervisitation among the teachers is one way of securing this understanding: Programs, plays and culminating activities to which other groups are invited is another solution.

In the light of past experiences, certain difficulties may be expected to be encountered. In the first place, there is always the problem of finding the proper reading materials to ald the children in solving their activity problems. There is also the problem of adjusting the activity to meet the individual differences of the pupils and of sustaining the interest of the children during the development of the activity.

Difficulties due to the lack of physical equipment will constantly present themselves. Since there is no library, laboratory or auditorium in the school, certain undesirable adaptations necessarily will have to be made. Collections of books from the public library will be used to supplement the books available for use in the school. The lack of a laboratory will preclude certain activities which demand its use. However, its lack will not prevent experimentation, 
observation and the development of a scientific attitude in problem attacking and problem solving generally. Moreover, it will not in any way affect the teaching of health needs, hygiene, and sanitation. We shall continue to use, as we are now using, the immediate environment as a laboratory for these experiences. The lack of an auditorium is one of our most serious handicaps. We are constantly limited by our inability to meet together as a group. Because of this limitation, we are planning regularly, some type of program in which all may participate. This is not only for the purpose of integration but also for the spirit of fellowshlp which the large group enterprise always engenders.

While these physical handicaps present a real problem and other difficulties are ever present, they have not discouraged us in the past nor shall we allow them to do so in the future. It is our hope to carry to a fuller realization our present activity program in the Nicholas Finzer School. 
BIBLIOGRAP HY 


\section{BIBLIOGRAPHY}

BOOKS

Adams, Fay. The Initiation of an Activity Program Into a Public School. Bureau of Publications, Teachers College, Columbia University, New York, 1934. 79 pp.

Bonser, Frederick G. Iife Needs and Education. Bureau of Publications, Teachers College, Columbia University, New York, 1932. 288 pp. Boyd, William. Towards a New Education. Alfred Knopf Company, New York, 1930. 497 pp. California Curriculum Commission. California Teachers Guide to Child Development. California State Printing Office, Sacramento, 1930. 658 pp. Carey, A.; Hanna, P.; and Meriam, J. I. Catalogue of Units of Work, Activities, Projects, Themes, etc. Bureau of Publications, Teachers College, Columbia University, New York, 1932. 290 pp. Clouser, Lucy W.; and Millikan, Chloe E. KindergartenPrimary Activities Based on Community Life. Macmillan Company, New York, 1929. 307 pp. Clouser, L. W.; Robinson, W. J.; and Neely, Dine L. Educative Experience through Activity Units. Lyons and Carnahan, New York, 1932. 307 pp. 
Cobb, Stanwood. The New Leaven. John Day Company, New York, 1928. 340 pp.

Coghill, G. E. Anatomy and the Problem of Behavior. Macmillan Company, New York, 1929. 113 pp. Duggan, S. P. A Student's Textbook in the History of Education. Appleton, New York, 1927. 413 pp. Ferriere, Adolphe. The Activity School. (Translated by F. Dean Moore and F. C. Wooten.) John Day, New York, 1927. $339 \mathrm{pp}$.

Harap, Henry. The Technique of Curriculum Making. . Macmillan Company, New York, 1928. 315 pp. Hartman, Gertrude; and Shumaker, Ann. Creative Expression. Edited for Progressive Education Association. John Day Company, New York, 1932. $350 \mathrm{pp}$.

Hissong, Clyde. The Activity Hovement. Warwick and York, Inc., Baltimore, 1932. $122 \mathrm{pp.}$ Jennings, Herbert; and others. Suggestions of

Modern Science Concerning Education. Macmillan Company, New York, 1917. 252 pp.

Keatinge, M. W. Comenius. McGraw-Hill, 1931. 255 pp. Kilpatrick, William H. Education for a Changing Civilization. Macmillan Company, New York, 1929. $136 \mathrm{pp}$. Knox, Rose. School Activities and Equipment. Houghton, Mifflin, Boston, 1927. $386 \mathrm{pp}$. 
Lewis, Mary. An Adventure with Children. Macmillan Company, New York, 1928. $250 \mathrm{pp}$.

Lincoln School Staff. Curriculum-Making in an Elementary

School. Ginn and Company, Boston, 1927. 359 pp. Meriam, J. I. Child Life and the Curriculum. World Book Company, Yonkers, 1920. 388 pp.

- Naumberg, Margaret; and others. Creative Expression

Through Art. Progressive Education Association, Washington, D. C., 1932. 193 pp.

National Society for the Study of Education: The Activity Movement; Thirty-third Yearbook, Part II. Public School Publiṣhing Company, Bloomington, Illinois, 1934. $315 \mathrm{pp}$.

Porter, Marthe Peck. Teacher in the New School.

World Book Company, Yonkers, 1930. 312 pp. Pratt, Caroline; and Stott, L. V. Adventuring with

Twelve Year-0lds. Greenberg, New York, 1927. 193 pp. Proceedings. National Education Association,

Washington, D. C., 1934. 1006 pp.

Recent Social Trends. McGraw-Hill, New York, 1927.

$1568 \mathrm{pp}$.

Rein, Wilhelm. Outlines of Pedagogics. (Translated by C. C. and I. J. Van Liew.) Kellogg, New York and Chicago, 1893. $225 \mathrm{pp}$. Rousseau. E'mile. (Translated by W. H. Payne.) Appleton, New York, 1914. 444 pp. 
Rugg, Harold; and Shumaker, Ann. The Child-Centered School. World Book Company, Yonkers, 1928. 359 pp. Salisbury, Ethel. An Activity Curriculum. Harr Wagner, San Francisco. 142 pp.

Storm, Grace E. Social Studies in the Primary Grades. Lyons and Carnahan, New York, 1932. 596 pp. Sweeney, Frances; Barry, E. F. and Schoelkopf, A. E. Western Youth Meets Eastern Culture. Teachers College, Columbia University, New York. 1932. 335 pp. Weiss, Albert Paul. A Theoretical Basis of Human Behavior. R. G. Adams and Company, Columbus, Ohio, 1929. $479 \mathrm{pp}$.

Wheeler, R. H.; and Perkins, F. T. Principles of

Mental Health and Development. T. Y. Crowell - Company, New York, 1932. 529 pp. Wrightstone, J. Wayne. Appraisal of Newer Practices in Selected Public Schools. Bureau of Publications, Teachers College, Columbia University, New York, 1935. $117 \mathrm{pp}$. 


\section{PERIODICAIS}

Barbour, Caroline W. "The Significance of Creative Activities in the Primary Grades." Education, pp. 454-460. April, 1932.

Beatty, Willard W. "Progressive Education in the Public Schools." Progressive Education, pp. 467-472. November, 1932 .

Beatty, W1llard W. "Training the Teacher for the New School." Progressive Education, pp. 247-253. May, 1933.

Boylson, E. R. "How Creative Projects Develop." School Arts, pp. 556-574. May, 1934. Brim, Orville. "Basic Realities and the Activity Movement." Progressive Education, pp. 328-333. October, 1934.

Collings, Ellsworth. "Learning the Fundamentals in the Activity Curriculum." Journal of Experimental Education, pp. 309-315. June, 1933. Courtis, Stuart A. "What is Progressive Education and What are Its Implications for Public Schools?" Educational Method, pp. 544-546. June, 1933. Darsie, Marvin L. "The Philosophic Origins of Progressive Education." School and Society, pp. 417-422. September,30, 1933. 
Demaiskev1tch, M. J. "Traditionalists Before a Progressive Tribunal." Educational Administration and Supervision, pp. 641-651. December, 1933.

- Dewey, John. "Why Have Progressive Schools?" Current History, pp. 44I-448. July, 1933. Dickson, Virgil E. "The Place of Scientific Research in the New Education." Educational Mothod, pp. 33\%-348. Apr11, 1934.

Fiman, Sidney G. "Taking the First Steps in Progressive Education." Progressive Education, pp. 30-34. January, 1935.

Friedrich, C. J. "This Progressive Education."

Atlantic Monthly, pp. 421-426. October, 1934. "Frontier Problems in Elementary Education."

Educational Method, pp. 1-9. October, 1933. (Summary of panel discussion, Department of Superintendence, Group V, Minneapolis, March 1, 1933.) Fuess, C. M. "Promise of Progressive Education." Current History, pp. 61-68. April, 1933. Gilbert, Lois. "A Visit to the Decroly School." Progressive Education, pp. 199-203. April, 1933. Hanna, Paul R. "An Activity Program in the Intermediate Grades - Part III: Its Development in Lincoln School Intermediate Grades." Education, pp. 483-488. Apr11, 1932. 
Hockett, John A. "The Activity Program in the Intermediate Grades - Part 1: Objectives and Standards." Education, pp. 471-476. April, 1932.

- Hopkins, L. Thomas. "Learning Essentials in an Activity Curriculum." Journal of Experimental Education, pp. 298-303. June, 1933.

Howell, Etta; Dunn, Maude; and Stoker, Dora. "Measuring the Skills in an Integrated Program." Journal of Experimental Education, pp. 316-319. June, 1933. Keliher, Alice V. "Where are the 'Progressives' Going?" Progressive Education, pp, 277-280. May, 1933. Keliher, Alice V. "What About Progressive Education?" Childhood Education, pp. 243-248. March, 1935. Kilpatrick, William H. "The Essentials of the Activity Movement." Progressive Education, pp. 346-359. October, 1934.

Meriam, J. I. "An Activity Curriculum in a School of Mexican Children." Journal of Experimental Education, pp. 309-315. June, 1933. Meriam, J. L. "The Traditional Curriculum of the High School is Challenged by the Activity Curriculum of the Elementary School." School and Society, pp. 169-177. August 11, 1934. Meyers, Edna R. "Experimental Possibilities in the Public Schools." Progressive Education, pp. 22-28. January, 1932. 
Morrison, J. Cayce. "Trends in Educational Method." Educational Method, pp. 129-137. December, 1933. "News of the Association." Progressive Education, pp. 485-436. November, 1933. Pistor, Frederick. "A Valid Scientific Appraisal of an Enterprise in Progressive Education." Journal of Educational Research, pp. 433-449. February, 1935. Pratt, Caroline. "Learning by Experience." Child Study, pp. 69-71. December, 1933. Reisner, E. H. "What is Progressive Education?" Teachers College Record, pp. 192-201. December, 1933. Saucler, W. A. "Psychology Teachers and Progressive Education." Educational Method, pp. 24l-24\%. February, 1934.

Skinner, H. Clay. "What Makes Progressive Education Progressive?" Educational Method, pp. 361-363. April, 1934.

Smith, L. W. "A Quantitative Study of an Activity Program." Elementary School Journal, pp. 669-677. May, 1933.

Snyder, Agnes. "The Activity Program in the Intermediate Grades - Part II: Its Inauguration." Education, pp. 476-482. April, 1932. 
Stern, Irene L. "An Extra-Curricular Activity Program for a Public Elementary School." Educational Method, pp. 530-543. June, 1933 .

Taba, Hilda. "Progressive Education - What Now?" Progressive Education, pp. 162-168, March,1934. Wrightstone, J. Wayne. "Measuring the 'Intangibles' in Progressive Schools." Progressive Education, pp. 95-97. February, 1935.

Wrightstone, J. Wayne. "An Evaluation of the Integrated Curriculum in the Upper Grades." Elementary School Journal, pp. 583-587. April, 1935.

Zirbes, Laura. "The Real Significance of Provision for Individual Differences." Education, pp. 441-445. Apri1, 1932.

Zirbes, Laura. "The Status of Progressive Schools."

Progressive Education, pp. 359-366. May, 1931. Zirbes, Laura. "What is 'Freedom' in the Classroom?"

Progressive Education, pp. 383-385. November, 1934. Zyve, Claire; and Merrill, Marie. "Analysis of Trends in an Informal Unit Teaching Program." Teachers College Record, pp. 293-309. January, 1934. 